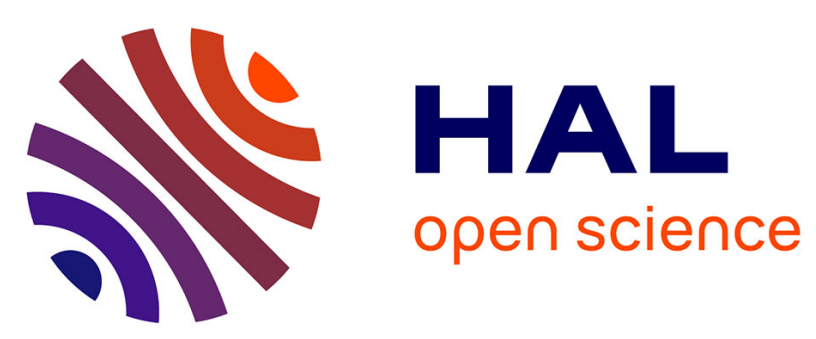

\title{
Effects of in situ CO2 enrichment on Posidonia oceanica epiphytic community composition and mineralogy
}

T. E. Cox, M. Nash, Frédéric Gazeau, M. Déniel, E. Legrand, S. Alliouane, P. Mahacek, A. Le Fur, Jean-Pierre Gattuso, Sophie Martin

\section{- To cite this version:}

T. E. Cox, M. Nash, Frédéric Gazeau, M. Déniel, E. Legrand, et al.. Effects of in situ CO2 enrichment on Posidonia oceanica epiphytic community composition and mineralogy. Marine Biology, 2017, 164 (5), pp.103. 10.1007/s00227-017-3136-7 . hal-01520318

\section{HAL Id: hal-01520318 https: / hal.sorbonne-universite.fr/hal-01520318}

Submitted on 10 May 2017

HAL is a multi-disciplinary open access archive for the deposit and dissemination of scientific research documents, whether they are published or not. The documents may come from teaching and research institutions in France or abroad, or from public or private research centers.
L'archive ouverte pluridisciplinaire HAL, est destinée au dépôt et à la diffusion de documents scientifiques de niveau recherche, publiés ou non, émanant des établissements d'enseignement et de recherche français ou étrangers, des laboratoires publics ou privés. 


\title{
Effects of in situ $\mathrm{CO}_{2}$ enrichment on Posidonia oceanica epiphytic community composition and mineralogy
}

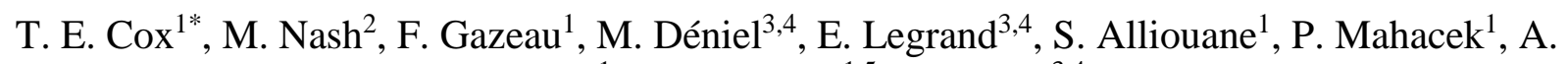 \\ Le Fur ${ }^{1}$, J.-P. Gattuso ${ }^{1,5}$, S. Martin ${ }^{3,4}$ \\ ${ }^{1}$ Sorbonne Universités, UPMC Univ Paris 06, CNRS-INSU, \\ Laboratoire d'Océanographie de Villefranche, 181 chemin du Lazaret, F-06230 Villefranche-sur- \\ mer, France \\ ${ }^{2}$ Research School of Physics, The Australian National University, Acton, Australian Capital \\ Territory 0200, Australia \\ ${ }^{3}$ CNRS, UMR 7144, Station Biologique de Roscoff, Place Georges Teissier, Roscoff Cedex \\ 29688, France \\ ${ }^{4}$ Laboratoire Adaptation et Diversité en Milieu Marin, Sorbonne Universités, UPMC Univ. Paris \\ 6, Station Biologique de Roscoff, Place Georges Teissier, Roscoff Cedex 29688, France \\ ${ }^{5}$ Institute for Sustainable Development and International Relations, Sciences Po, 27 rue \\ Saint Guillaume, F-75007 Paris, France \\ *Corresponding author: erincox@hawaii.edu
}

20 Running page head: In situ $\mathrm{CO}_{2}$ enrichment on epiphytes

21 ABSTRACT: Alterations in seagrass epiphytic communities are expected under future ocean

22 acidification conditions, yet this hypothesis has been little tested in situ. A Free Ocean Carbon

23 Dioxide Enrichment (FOCE) system was used to lower $\mathrm{pH}$ by a $\sim 0.3$ unit offset within a

24 partially enclosed portion $\left(1.7 \mathrm{~m}^{3}\right)$ of a Posidonia oceanica meadow (11 $\mathrm{m}$ depth) between 21

25 June and 3 November 2014. Leaf epiphytic community composition (\% cover) and bulk

26 epiphytic mineralogy were compared every four weeks within three treatments, located in the

27 same meadow: a pH-manipulated (experimental enclosure) and a control enclosure, as well as a

28 nearby ambient area. Percent coverage of invertebrate calcifiers and crustose coralline algae

29 (CCA) did not appear to be affected by the lowered $\mathrm{pH}$. Furthermore, fleshy algae did not

30 proliferate at lowered $\mathrm{pH}$. Only Foraminifera, which covered less than $3 \%$ of leaf surfaces,

31 declined in manner consistent with ocean acidification predictions. Bulk epiphytic magnesium

32 carbonate composition was similar between treatments and percentage of magnesium appeared 
33 to increase from summer to autumn. CCA did not exhibit any visible skeleton dissolution or

34 mineral alteration at lowered $\mathrm{pH}$ and carbonate saturation state. Negative impacts from ocean

35 acidification on P. oceanica epiphytic communities were smaller than expected. Epiphytic

36 calcifiers were possibly protected from the $\mathrm{pH}$ treatment due to host plant photosynthesis inside

37 the enclosure where water flow is slowed. The more positive outcome than expected suggests

38 that calcareous members of epiphytic communities may find refuge in some conditions and be

39 resilient to environmentally-relevant changes in carbonate chemistry.

41 KEY WORDS: ocean acidification, seagrass-epiphyte interactions, calcifiers, magnesium

42 carbonate, coralline algae, Bryozoa, $\mathrm{pH}$, remineralisation

\section{Introduction}

Seagrass leaves and rhizomes are colonized by taxonomically diverse animal and algal

46 representatives referred to as epiphytes following the definition of Steel and Wilson (2003).

47 Seagrass and epiphytes form meadows which are highly valued for the services they provide

48 (Hemminga and Duarte 2000). For example, they play a fundamental role in maintaining

49 populations of exploited fisheries (Jackson et al. 2015). In the Mediterranean Sea, the seagrass

50 Posidonia oceanica L. (Delile) covers $23 \%$ of shallow water substratum $(<50 \mathrm{~m}$, Pasqualini et

51 al. 1998) and leaf epiphytes can constitute $\sim 30 \%$ of the canopy biomass (Prado et al. 2008).

52 Seagrass leaf epiphytes include coralline and filamentous algae, polychaetes, foraminiferans, and

53 bryozoans (Borowitzka et al. 2006). Among these groups are several calcifiers (e.g. coralline

54 algae, foraminiferans, serpulid polychaetes and some bryozoans) which contribute to carbonate

55 cycling (Frankovich and Zieman 1994; Perry and Beavington-Penney 2005). Moreover, $P$. 
oceanica epiphytes can contribute 20 and $60 \%$ to meadow primary production and nutrient

57 uptake (Borowitzka et al. 2006; Lepoint et al. 2007). Most herbivores feed on algal epiphytes and

58 several grazers feed on the epiphytic invertebrates (Lepoint et al. 2000). As evidence of their

59 importance as a food source, epiphyte abundance and herbivore dynamics are tightly coupled

60 (Tomas et al. 2005).

61 Through the process of ocean acidification, the $\mathrm{pH}$ in the ocean is being lowered with a

62 subsequent decline in the proportion of carbonate ions $\left(\mathrm{CO}_{3}{ }^{2-}\right)$ and an increase in the proportions

63 of bicarbonate ions $\left(\mathrm{HCO}_{3}^{-}\right)$and dissolved carbon dioxide $\left(\mathrm{CO}_{2}\right)$. Surface ocean $\mathrm{pH}$ decreased by

640.1 units since the pre-industrial era and an additional 0.07 to 0.33 units decrease is expected by

652100 (Gattuso et al. 2015). The decline in the $\mathrm{CO}_{3}{ }^{2-}$ concentration is projected to affect the

66 ability of calcifying organisms to maintain their skeletons (Feely 2004; Kroeker et al. 2013).

67 Macroalgal species can also respond differently to the increased carbon available for

68 photosynthesis and many, without calcified surfaces, are thought to be better competitors under

69 future ocean acidification conditions (Beer and Koch 1996; Koch et al. 2013). The concern is

70 changes in competitive abilities may cause shifts in composition at the community level (Fabry

71 et al. 2008; Kroeker et al. 2012; Gaylord et al. 2015; Sunday et al. 2017).

72 Seagrass epiphytic coverage and composition examined under lower $\mathrm{pH}$ conditions near

$73 \mathrm{CO}_{2}$ vents and in the laboratory generally support future ocean predictions based upon

74 physiology and mineralogy. The epiphytic calcified community, which is often dominated by

75 crustose coralline algae (CCA), is less abundant at lowered $\mathrm{pH}$. Furthermore, epiphytic

76 invertebrates with lower $\mathrm{Mg}$ content and those organisms that lack calcified skeletons, such as

77 filamentous algae, often persist at lowest $\mathrm{pH}$ conditions (Martin et al. 2008; Campbell and

78 Fourqurean 2014; Donnarumma et al. 2014; Cox et al. 2015). The predicted loss of CCA at 
79 lowered $\mathrm{pH}$ is a global concern for ecosystem function. Species of CCA occur in temperate and

80 tropical seagrass beds and in a variety of other habitats ( $<295 \mathrm{~m}$ depth) where they serve key

81 ecological roles (Littler and Littler 2013). They are known to be a food source, cement and

82 stabilize reefs, facilitate recruitment, and add significantly to sediments (Land 1970; Nelsen and

83 Ginsburg 1986; Littler and Littler 2013; Gischler et al. 2013). Although vent systems predict

84 their loss and shifts in the community under ocean acidification, they are not perfect predictors of

85 future ocean ecology owing to the large variability of $\mathrm{pH}$ in space and time (Hall-Spencer et al.

86 2008; Kerrison et al. 2011). Furthermore, laboratory experiments have difficulties accounting for

87 the many environmental variations and species interactions that can alter predicted outcomes

88 (e.g. Burnell et al. 2014). Therefore, predictions on the fate of $P$. oceanica meadows could

89 benefit from additional information provided by the manipulation of $\mathrm{pH}$ in situ on entire

90 communities for an extended period of time (months to years).

91 Alteration in the abundance of $P$. oceanica epiphytes will likely have repercussions to

92 meadow carbon cycling and feeding capacity. Therefore, the aim of the present study was to test

93 the hypothesis that $P$. oceanica epiphytic community will be impacted by ocean acidification.

94 We tested this hypothesis in situ with a Free Ocean Carbon Dioxide Enrichment (FOCE) system

95 (see Gattuso et al. 2014). This system allows $\mathrm{pH}$ to be manipulated continuously, in an

96 enclosure, at a fixed offset from ambient levels. The offset takes into account natural $\mathrm{pH}$

97 fluctuations that may alter organismal responses. During a 4 month-experimental period,

98 epiphytic coverage as well as carbonate mass was quantified on Posidonia leaves. Lastly, some

99 minerals in epiphytic calcified structures are more susceptible to dissolution and mineral changes

100 at elevated partial pressure of $\mathrm{CO}_{2}\left(p \mathrm{CO}_{2}\right)$ are not well understood. Therefore, we analyzed

101 epiphytic mineralogy throughout the duration of the study. 
103 Methods

104 Experimental setup and system function

105 This study used the European FOCE (eFOCE) system which allows for the in situ

106 manipulation of $\mathrm{pH}$ in benthic enclosures as an offset from ambient $\mathrm{pH}$ (Gattuso et al. 2014). The

107 system was deployed in the Bay of Villefranche, approximately $300 \mathrm{~m}$ from the Laboratoire

108 d'Océanographie de Villefranche (NW Mediterranean Sea, France; $43^{\circ} 40.7^{\prime} \mathrm{N}, 07^{\circ} 19.39^{\prime} \mathrm{E}$ ).

109 The study design consisted of two clear, $1.7 \mathrm{~m}^{3}$ (2 m long x $1 \mathrm{~m}$ width $\mathrm{x} 0.85 \mathrm{~m}$ tall)

110 perspex enclosures that enclosed a portion of a $P$. oceanica meadow. The enclosures were

111 located at $11 \mathrm{~m}$ depth and were placed approximately $1.5 \mathrm{~m}$ apart. The $\mathrm{pH}$ in one enclosure,

112 referred to as the experimental enclosure, was lowered by $\sim 0.3$ units as an offset from ambient

$113 \mathrm{pH}$ as measured on the total scale. This offset was based upon the business-as-usual

114 representative concentration pathway RCP8.5 following Ciais et al. (2013) and corresponded to a

115 mean $( \pm \mathrm{SD}) \mathrm{pH}_{\mathrm{T}}$ of $7.75 \pm 0.13$ and $p \mathrm{CO}_{2}$ of $971 \pm 323 \mu \mathrm{atm}$. In the second enclosure, the $\mathrm{pH}$

116 was not manipulated and it served as a control. A third treatment consisted of an open fiberglass

117 frame of the same dimensions as the enclosure footprint $\left(2 \mathrm{~m}^{2}\right)$. It was placed nearby $(3 \mathrm{~m}$ of the

118 experimental enclosure) and in the same meadow. It is referred to as a reference plot and was

119 used to account for any effects generated by the enclosure structure. True replication was not

120 logistically feasible. Replication was sacrificed to 1) control $\mathrm{pH}$ precisely within enclosures of a

121 large enough size to contain $P$. oceanica and 2) sense $\mathrm{pH}$ and other aspects of the environment

122 continuously in the three treatment locations.

123 The details of the eFOCE system function and maintenance are described in Cox et al.

124 (2016) and a schematic can be found in Supplemental Figure 1 (Fig. S1). Briefly, the pH in the 
125 experimental enclosure was altered using surface supplied seawater pumped into a mixing tank,

126 which was located on a surface platform. Pure $\mathrm{CO}_{2}$ was bubbled into the mixing tank and the

127 resulting low $\mathrm{pH}$ seawater was pumped (flow rate up to $0.12 \mathrm{~L} \mathrm{~min}^{-1}$ ), via tubing, underwater to

128 the proximity of the benthic enclosures. Prior to entering the enclosures, low $\mathrm{pH}\left(\mathrm{pH}_{\mathrm{T}} \sim 5.5\right)$ and

129 ambient seawater were mixed in an underwater tube and a set (x3) of centrifugal pumps $(6.7 \mathrm{~L}$

$130 \mathrm{~min}^{-1}$ each) injected ambient seawater in the control enclosure and lowered-pH seawater in the

131 experimental enclosure. Seawater $\mathrm{pH}$ was measured before entering the enclosures enabling the

132 automated adjustment of the low $\mathrm{pH}$ seawater injection to maintain the desired $\mathrm{pH}$ offset.

133 Seawater inside enclosures was circulated by a set of centrifugal pumps (4 per chamber; $6.7 \mathrm{~L}$

$134 \mathrm{~min}^{-1}$ each) and exited through two openings (12 cm diameter). The renewal time of seawater in

135 each enclosure was ca. $1.5 \mathrm{~h}$. The system contained a number of sensors: 4 potentiometric

136 Seabird 18-S pH sensors located inside each enclosure and in each mixing tube and three Seabird

13737 SMP-ODO CTD with SBE $63 \mathrm{O}_{2}$ optodes and three LI-COR-192 PAR (photosynthetic active

138 radiation) sensors located in each enclosure and one nearby the enclosures (in ambient). The

139 carbonate chemistry within each treatment was determined at high frequency using average total

140 alkalinity together with sensed temperature, salinity and $\mathrm{pH}_{\mathrm{T}}$, in the $\mathrm{R}$ package, seacarb (see Cox

141 et al. 2016 for more details).

\section{Timeline}

143 The experiment comprised three periods in 2014: (1) the pre-acidification period, before

$144 \mathrm{pH}$ was manipulated, from 15 May to 11 June, (2) the transition period from 12 to 21 June, when

$145 \mathrm{pH}$ in the experimental enclosure was slowly lowered by no more than 0.05 units per day until an

146 offset of approximately -0.3 units was reached and (3) the experimental period from 22 June to 3

147 November when $\mathrm{pH}$ in the experimental enclosure was maintained at a offset of $\sim-0.3$ units. 


\section{Collection of seagrass leaves}

Six to ten oldest leaf blades were collected from separate $P$. oceanica shoots growing within the reference plot and enclosures. Oldest leaf blades, or the outer most leaf in the bundle,

151 were selected because these blades have more developed epiphytic communities (Cebrián et al.

152 1999). Divers collected intact leaves spaced evenly throughout the plot or enclosure at

153 approximately four week intervals during the acidification period in 2014, at time (T) 1 to 4: T1

154 occurred on 31 July, $39 \mathrm{~d}$ after acidification, T2 occurred on 4 September, $74 \mathrm{~d}$ after

155 acidification, T3 on 9 October after $109 \mathrm{~d}$ of acidification and T4 occurred on 10 November after

$156135 \mathrm{~d}$ of acidification. It should be noted that the acidification of the experimental enclosure

157 ended on 4 November 2014 but due to logistical constraints the final collection of blades were

158 made six days later. A set of ten leaves was also collected immediately after the transition period, 159 on 26 June 2014 (referred to as sampling interval, T0). These leaves were collected in a $2 \times 1 \mathrm{~m}$

160 area in the meadow, located $\sim 2 \mathrm{~m}$ from the enclosures. They were collected outside the

161 enclosures and the reference plot to limit destructive sampling within the experimental setup but

162 still obtain a baseline measure. All leaves were collected above the sheath, placed into separate

163 plastic bags, transferred into a darkened cooler, and transported to the laboratory.

\section{Determination of epiphytic coverage and composition}

165 Leaves used for determination of epiphytic coverage and composition were kept in a 166 temperature controlled $\left(20\right.$ to $\left.22^{\circ} \mathrm{C}\right)$, darkened room for less than $24 \mathrm{~h}$ until scanning was

167 completed. A high-resolution scanner ZooScan (Hydroptic, France; Gorsky et al. 2010) produced 168 colour images ( $2400 \mathrm{dpi}$ ) of leaves and their epiphytes. Five to seven images of leaves were used

169 to represent the assemblage within the reference plot and enclosures at each interval, except at

170 T1 when error resulted in three to four scanned leaf images being used per treatment. 
172 the scanned image of the leaf. Organisms that occurred directly underneath each intersection of

173 the grid or point (231 to 1244 depending upon leaf length) were identified to the lowest possible

174 taxonomic or functional unit and counted. Fifteen lowest possible taxonomic or functional

175 groups were identified. These 15 were lumped into 11 groups that shared functional or

176 taxonomic similarity (see Table S3). The 11 groups were as follows: CCA (pigmented if pink in

177 coloration or bleached if thallus appeared white), non-calcified algae, Bryozoa, serpulid

178 polychaetes, Foraminifera, Hydrozoa, Porifera, unidentified, biofilm and ascidians. Biofilm was

179 defined as a group of microscopic organisms that formed a visible film across the surface of the

180 leaf. SEM images indicated this group is likely composed of diatoms and bacterial films and rod

181 forms. Percent cover by organism (or unit) was determined for each leaf by dividing the

182 organism intersections by the total number of intersections analysed and multiplying by 100 .

183 Calcium carbonate mass

184 After scanning, the mass of $\mathrm{CaCO}_{3}$ contained in the epiphytes was assessed using the 185 weight loss after acidification method (Bosence 1989; Perry and Beavington-Penney 2005).

186 Leaves with epiphytes were dried at $60{ }^{\circ} \mathrm{C}$ for $12 \mathrm{~h}$, weighed $(A, 0.01 \mathrm{mg})$, acidified with $5 \%$

$187 \mathrm{HCl}$, rinsed twice with deionised water, dried again at $60{ }^{\circ} \mathrm{C}$ for $12 \mathrm{~h}$ and re-weighed $(B)$. Ten

188 young leaves without epiphytes were treated in the same manner $(C)$. The weight of the epiphytic 189 calcareous mass was then determined from the following equation, $A-[B /(1-C)]$.

\section{Determination of mineralogy}

191 After each leaf collection, three leaves from each treatment were set aside to air-dry ( $\sim 22$

$192{ }^{\circ} \mathrm{C}$ ) at room temperature. Dried epiphytes were gently scraped from separate leaves and ground

193 into a fine powder for X-ray diffraction (XRD, $N=3$ per treatment). Additionally, to obtain a 
194 baseline mineral profile the XRD analysis was performed on separate Bryozoa and CCA

195 sampled at T0 and carefully removed from the leaves and ground. Scanning electron

196 microscopy-energy dispersive spectroscopy (SEM-EDS) was further used to understand how the

197 minerals identified by XRD, were present on the leaf surface. Using SEM-EDS we compared the 198 skeletal structure of CCA between treatments.

199 XRD was carried out using a SIEMENS D501 Bragg-Brentano diffractometer equipped 200 with a graphite monochromator and scintillation detector, using $\mathrm{CuK} \alpha$ radiation. Settings were a 201 step size of $0.02^{\circ}$ and a scan speed of $1^{\circ}$ per minute. Precision for determination of Mg-content 202 of Mg-calcite was $\sim 0.5 \%$. Scan interpretation followed procedures described in Nash et al.

203 (2014). SEM-EDS was done using a Zeiss UltraPlus field emission scanning electron

204 microscope, equipped with an Oxford Inca EDS. For EDS measurements, the Zeiss was set to $20515.0 \mathrm{kV}, 15 \mathrm{~mm}$ working distance with a beam interaction volume ca. $3 \mu \mathrm{m}$. Imaging was at $2063 \mathrm{~mm}$ working distance and $3 \mathrm{kV}$. Samples were platinum coated. A sample was embedded in 207 crystal bond and polished for precise SEM-EDS measurements or mounted intact and attached 208 using carbon tape. Aragonite was quantified using the area under the curve method (Diaz-Pulido 209 et al. 2014). Many Mg-calcite peaks had minor asymmetry on the lower 2-theta side indicating

210 the presence of small amounts of calcite. Comparisons of relative calcite asymmetry were made

211 using the principles of peak asymmetry developed in Nash et al. (2014).

\section{Statistical analyses}

213 The approach used was to monitor the epiphytic community at three sites: control

214 enclosure, experimental enclosure, and a reference plot. This study, similar to many natural

215 experiments, lacks true replication (Hurlbert 1984). In unreplicated designs in ecology, the

216 emphasis is on the estimation of effect size and the unique ecological perspective provided 
217 (Hurlbert 1984; Stewart-Oaten et al. 1986; Oksanen 2001; Davies and Gray 2015). Inferential

218 statistics were avoided. Furthermore, a large effect size was expected based upon previous study

219 results (e.g. Martin et al. 2008).

220 Multivariate analyses were used to compare the leaf epiphytic communities. Prior to 221 analyses, the epiphytic coverage at each interval was averaged. Thus, there was one value for

222 each of the three treatments (reference, control enclosure, and the experimental enclosure) at 223 each interval (T1-T4). A square root transformation was applied and a Bray-Curtis resemblance

224 matrix created between each interval-treatment assemblage ( 4 intervals $\mathrm{x} 3$ treatments $=12$ leaf

225 assemblages). Dissimilarities were visualized with an nMDS (non-metric multi-dimensional

226 scaling) plot. A two-way (treatment x interval) Analysis of Similarity (ANOSIM) without

227 replication and 999 permutations was used to examine for differences. This is a valid approach in 228 ecological monitoring when there is pseudoreplication (Clarke 1993). The global R from an

229 ANOSIM indicates effect size. It ranges from -1 to 1 and is analogous to a correlation

230 coefficient; a value close to zero indicates no or little distinction between a prior groups. The

231 ANOSIM was followed by two separate (treatment and interval) similarity percentage analyses

232 (SIMPER) to identify the amount each taxonomic or functional group contributed to

233 dissimilarity.

234 Data from leaves collected at T0 (before the perturbation) were not used in multivariate

235 analyses because they were only collected at one instance and outside the experimental setup.

236 Similarly, organisms that occurred on one to three leaves out of 70 were removed prior to

237 analyses to eliminate their inflated influence on dissimilarities.

238 The abundance (mean, median, and range) of specific taxa, $\mathrm{CaCO}_{3}$ mass, and epiphytic

239 mineral composition were compared qualitatively through time between the three treatments; 
240 paying careful attention to any directional deviations observed on leaves from the experimental

241 enclosure.

242 Results

243 Environmental and experimental conditions

244 Environmental and experimental conditions as well as seagrass growth are fully

245 described in Cox et al. (2016). There were 150 to 175 shoots $\mathrm{m}^{-2}$ of $P$. oceanica inside each plot 246 and enclosure and few other macrophytes ( $<11 \%$ coverage). Leaf biometrics were not affected

247 by the lowered $\mathrm{pH}$. Average shoot height increased from $40.6 \mathrm{~cm}$ in April to $73.4 \mathrm{~cm}$ in August 248 then declined to $24.8 \mathrm{~cm}$ in November.

249 The carbonate chemistry is summarized in Table 1 and the diel variability is provided in

250 Table $\mathrm{S} 1$. The $\mathrm{pH}_{\mathrm{T}}$ in the meadow (ambient) ranged from a monthly mean of $7.98( \pm 0.06 \mathrm{SD})$ to

$2518.11( \pm 0.04 \mathrm{SD}$, Table 1$)$. The mean saturation states of aragonite $\left(\Omega_{\mathrm{a}}\right)$ and calcite $\left(\Omega_{\mathrm{c}}\right)$ ranged

252 from 3.1 to 3.6 and 4.9 to 5.4 from June to September, respectively. The diel $\mathrm{pH}_{\mathrm{T}}$ change

253 differed among months from 0.04 to 0.12 . It corresponded to the daily change in $\mathrm{CO}_{2}$

254 concentration driven by community primary production, respiration and calcification.

255 The carbonate chemistry in the control enclosure and the ambient environment were

256 similar (monthly mean differed $\leq 0.06$ units). The diel change in $\mathrm{pH}_{\mathrm{T}}$ within the control

257 enclosure was slightly greater than in ambient and was consistent in the pre- and during

258 acidification period (median \pm median absolute deviation $0.14 \pm 0.06$ and $0.14 \pm 0.06$ ).

259 During the acidification period, the $\mathrm{pH}$ in the experimental enclosure was maintained at a

260 mean -0.26 unit offset (monthly mean values from -0.22 to $-0.29 \mathrm{pH}$ units) from the control

261 enclosure (Table S1). Monthly mean values of saturation state with respect to aragonite $\left(\Omega_{\mathrm{a}}\right)$

262 ranged from $2.0( \pm 0.05 \mathrm{SD})$ in October to a high of $2.5( \pm 0.06 \mathrm{SD})$ in August and saturation 
263 state with respect to calcite $\left(\Omega_{\mathrm{c}}\right)$ ranged from $3.0( \pm 0.07$ to $0.008 \mathrm{SD})$ in September and October

264 to $3.8( \pm 0.09 \mathrm{SD})$ in August. Median diel $\mathrm{pH}$ range in the experimental enclosure was two to

265 three times larger than the control (monthly ranged from 0.09 to $0.29 \mathrm{pH}$ units) and had greater

266 variability. Variation was attributed to lowered buffering capacity of seawater with lowered $\mathrm{pH}$.

267 Monthly differences as summarized in Cox et al. (2016) were evident, particularly for

268 temperature (mean monthly range: 17.7 to $24.2^{\circ} \mathrm{C}$ ) and PAR (mean monthly range: 1.3 to 7.3

269 mol photons $\mathrm{m}^{-2} \mathrm{~d}^{-1}$, Table S2) but were similar in the ambient, control and experimental

270 enclosures.

\section{Leaf epiphytic community description}

272 Overall, CCA were the most dominant epiphyte occurring on all leaves at coverages

273 between 0.8 to $58.8 \%$, followed by the lesser abundant biofilm (0 to $22.0 \%$ ) and Bryozoa (0 to

$27420.8 \%$ ). Hydroids and sponges were found on 3 of the 70 leaves $(<2 \%)$. An ascidian occurred at

$27512 \%$ on one leaf collected from the reference plot.

276 SEM images confirmed the presence of CCA, Bryozoa, Foraminifera, serpulid

277 polychaetes and biofilm. At this increased SEM resolution, bacterial films, rod structures and

278 diatoms were visually distinguishable. These organismal groups were likely undetected or

279 grouped to 'biofilm' in the quantification of macroepiphytes. Unidentified rod structures of 1-2

$280 \mu \mathrm{m}$ in length were commonly found on the epiphytes but not directly on the leaves (Fig. S2).

281 Diatoms were observed both on epiphytes and leaf surfaces.

\section{Spatial and temporal patterns in epiphytic community}

283 There was little distinction in epiphytic composition and coverage found on leaves from

284 the enclosures and reference plot yet, clear differences were observed between T1-T4 intervals 
285 (ANOSIM: treatment, global $\mathrm{R}=0.25$, $\mathrm{p}$-value $=0.28$; interval, global $\mathrm{R}=0.56, \mathrm{p}$-value $=$ $286 \quad 0.003$; Fig. 1)

287 Indeed, SIMPER routine indentified dissimilarities (TS4) between communities in the 288 plot and enclosures to be small (ranged from 19.2 to 26.7\%). Differences in abundances of 289 biofilm and pigmented CCA contributed most (Table S4, 19.1 to 33.3\%) to treatment 290 dissimilarities. Leaves from the reference plot had an overall (across all sampling intervals, $\mathrm{n}=$ 29118 to 20 leaves) greater coverage of pigmented CCA (mean $\pm \mathrm{SD}$, reference $=27.9 \pm 15.3$, 292 control $=19.5 \pm 9.4$ and experimental $=23.4 \pm 10.7 \%)$ and leaves from the control had a greater 293 cover of biofilm (mean $\pm \mathrm{SD}$, reference $=0.8 \pm 0.9$, control $=7.2 \pm 5.3$, experimental $=2.8 \pm$ $2942.5 \%$ ). It was also noted that there was a greater coverage of biofilm in enclosure communities, 295 with percentages more similar to those observed at T0 in leaves from the ambient. In SEM 296 images, relatively greater numbers of diatoms were observed on leaves collected in the 297 enclosures than on leaves collected at T0 and in the reference plot.

298 Dissimilarity in communities increased with increasing duration between sampling 299 intervals. For example, the overall (combined treatments) community at T1 was most dissimilar 300 from communities at T3 and T4 (20.9 to 30.2\% dissimilar, respectively) and least dissimilar from 301 the community at $\mathrm{T} 2(14.1 \%)$. Also, the community at $\mathrm{T} 2$ was more similar to the community at $302 \mathrm{~T} 3$ than the community at T4 (Table S5, T2 and T3 were $18.2 \%$ dissimilar, T2 and T4 were $30326.7 \%$ dissimilar).

304 In enclosures and in the reference plot, there was a decline in the abundance of CCA 305 (bleached and pigmented, separate groups in analyses) from July (mean \pm SD, T1 $31.4 \pm 8.3 \%$ )

306 to November (mean \pm SD, T4 $11.7 \pm 6.2 \%$ ). Bleached and healthy appearing CCA showed 307 similar trends in time. Together, they accounted for 33 to $55 \%$ of the dissimilarity between 
308 intervals. Other epiphytic groups also declined from T1 to T4 and contributed to interval

309 dissimilarities (each contributed between 4.1 to 13.7\%), these included non-calcified algae (mean

$310 \pm \mathrm{SD}, \mathrm{T} 12.2 \pm 2.7 \%$ to $\mathrm{T} 40.3 \pm 0.4 \%$ ) and Bryozoa (mean $\pm \mathrm{SD}, \mathrm{T} 12.1 \pm 1.4 \%$ to $\mathrm{T} 40.5 \pm$

$3110.6 \%)$.

312 The abundances of epiphytes found on the T0 leaves $(n=7$, collected from nearby

313 enclosures before the pertubation), highlight the large spatial or temporal variability in

314 abundance of some groups, such as Bryozoa and Foraminifera (Fig 2).

315 Trends in organismal coverage to evaluate predicted $\mathbf{p H}$ effects

316 Overall (pooled across sampling intervals), leaves from the experimental enclosure had a

317 slightly greater mean coverage of pigmented CCA than those from the control enclosure (Fig. 2

318 A) and the range of coverage often overlapped. The coverage of non-calcified algae (Fig. 2D,

319 mostly Dictyota sp.) declined in all treatments and the overall mean $( \pm \mathrm{SD})$ was slightly lower in

320 the experimental than in the control enclosure $(1.2 \pm 1.8 \%$ vs $0.7 \pm 0.7 \%)$. It contributed $4.7 \%$ to

321 enclosure differences. Leaves from the experimental enclosure also tended to have a relatively

322 greater coverage of invertebrate calcifiers (Fig. 2E, F; mean \pm SD, control versus experimental,

323 Bryozoa: $0.6 \pm 0.8 \%$ vs $1.0 \pm 0.9 \%$; serpulid polychaetes: $0.1 \pm 0.1 \%$, vs $0.4 \pm 0.4 \%$ ). These

324 abundances contributed 8\% each to differences between enclosures. Only, leaf epiphytic

325 Foraminifera (Fig. 2G) had a directional change in abundance distinct from the change in

326 abundances on leaves from the control enclosure and reference plot. Foraminifera coverage was

327 greatest on leaves at $\mathrm{T} 1$ within the experimental enclosure ( 0 to $1 \%)$, they declined at $\mathrm{T} 2$ ( 0 to

$3280.1 \%$ ) and disappeared from the collected leaves at T3 and T4. However, this taxon is rare

329 (indicated by low coverage, $<1 \%$ ) and coverage between leaves can be highly variable (see T0).

330 It contributes 7\% to enclosure community differences (Table S4). 


\section{Calcium carbonate mass}

$\mathrm{CaCO}_{3}$ mass on leaves ranged from 8.6 to $24.7 \mathrm{mg} \mathrm{cm}^{-2}$ (Fig. 3). There were no clear

333 consistent patterns that would indicate seasonal changes or lowered $\mathrm{pH}$ effect.

\section{Mineralogy}

The magnesium carbonate composition of leaf epiphytes ranged from 10.6 to $13.2 \mathrm{~mol} \%$

$336 \mathrm{MgCO}_{3}$ and there was no indication of a low $\mathrm{pH}$ effect (Fig. 4). The mean ( $\left.\pm \mathrm{SD}\right) \mathrm{mol} \% \mathrm{MgCO}_{3}$

337 was $11.9 \pm 0.6$ on leaves from the reference plot, $12.1 \pm 0.9$ on leaves from the control and 12.0

$338 \pm 0.7$ on leaves from the experimental enclosure. Values obtained on samples collected at T0

339 confirmed that CCA and Bryozoa were, respectively, 11.3 to 11.7 and 8.3 to $8.8 \mathrm{~mol}^{2} \mathrm{MgCO}_{3}$.

340 Changes in epiphytic mol\% $\mathrm{MgCO}_{3}$ by sampling interval appeared to be seasonal (Fig.4).

341 The community mean $( \pm \mathrm{SD})$ value tended to increase from T0 (June, $10.7 \pm 0.1$ ) to T1 (July,

$34211.1 \pm 0.4$ ) and maintained a similar composition between T2 and T4 (September to November,

$34312.2 \pm 0.4$ and $\left.12.4 \pm 0.6 \mathrm{~mol} \% \mathrm{MgCO}_{3}\right)$

344 There were two other mineral phases present in the epiphyte community in addition to

345 magnesium calcite, calcite and aragonite. Aragonite was present on all 24 leaves examined from

346 the enclosures but was not present on leaves collected from the reference plot, nor from T0

347 leaves from the ambient environment (16 leaves in total). The proportion of aragonite in bulk

348 epiphytes between enclosures was similar at each interval from T1 to T3. At T4, it was greater in

349 two of the three epiphyte samples collected from the control enclosure and in three of three

350 samples collected from the experimental enclosure (Fig. 4).

351 Calcite was predominantly present in epiphytes collected from the reference plot and at

352 T0 in ambient epiphytes (Fig. 4). Epiphytes from the ambient environment at T0 and T1 to T3 in

353 the reference plot had minor calcite amounts present as indicated by slight asymmetry of the $\mathrm{Mg}$ - 
354 calcite peak. There were separate peaks for calcite and Mg-calcite for bulk epiphytes at T4,

355 indicating substantial amounts present, but they were not quantified. The asymmetry method is

356 not appropriate when the peaks are entirely separate, as for the T4 samples. In this case the value

357 of (-) 6 was given, being the approximate difference between the value for calcite (which

358 contains $\sim 3-4 \mathrm{~mol} \% \mathrm{MgCO}_{3}$ ) and $\mathrm{Mg}$-calcite (9-10 mol\% $\left.\mathrm{MgCO}_{3}\right)$.

359 SEM-EDS was used to visualize the surfaces of leaf epiphytes and examine the location

360 of mineral phases. Imaging was undertaken on subsamples from three leaves collected at T0

361 from the ambient environment and from both enclosures and reference plot at T1 and T4. Loose

362 grains of Mg-calcite were present on the seagrass surface (Fig. S3). These appeared to be

363 remnant grains after the surficial CCA had broken off, possibly during sample preparation.

364 Calcification features of the CCA from the enclosures and reference plot appeared similar in

365 structure (Fig. 5). There were not any structural indications of dissolution from the lowered $\mathrm{pH}$.

366 EDS measurements also confirmed that the CCA were Mg-calcite.

367 All the imaged CCA had areas of alteration where their cellular structure was no longer

368 intact (Fig. 6). EDS measurements showed that alteration areas were responsible for the calcite

369 or aragonite identified by XRD. Altered surfaces of epiphytic CCA revealed different mineral

370 phases related to a "structural effect" from the enclosures. On leaves from the ambient

371 environment (reference plot as well as T0), the altered CCA surfaces appeared rough and were

372 composed of calcite with no micro-endoliths visible. In contrast, the altered surfaces of CCA on

373 leaves from the enclosures were aragonitic. The aragonite-altered CCA showed areas that

374 appeared similar to the calcitic altered areas on CCA from the ambient, with the exception that

375 there were also partially eroded cells that had altered to aragonite (Fig. 6, Fig. S4). Crystal

376 morphology of the aragonite varied from blocky to typical aragonite needle shape. Particular 
377 attention was paid to the November samples from the reference plot to determine whether there

378 were other epiphytes or changes that could be responsible for the substantially greater amount of

379 calcite observed relative to the amount observed at $\mathrm{T} 0$ and $\mathrm{T} 1$ in the epiphytes grown in the

380 ambient environment. The only calcite detected was in alteration areas that appeared similar to

381 that observed previously at T0 and T1. Diatoms and bacterial films were observed on the

382 surfaces of leaves and CCA, often in close proximity to the altered algal surfaces (Fig. S4).

\section{Discussion}

The lack of a $\mathrm{pH}$ effect on $P$. oceanica epiphytic community is in contrast with findings

385 from previous laboratory manipulations and observations of communities conducted near $\mathrm{CO}_{2}$

386 vents where the $\mathrm{pH}$ is naturally lower (Hall-Spencer et al. 2008; Martin et al. 2008;

387 Donnarumma et al. 2014; Cox et al. 2015). Martin et al. (2008) showed a complete

388 disappearance of epiphytic coralline algae and the persistence of bryozoans at an average $\mathrm{pH}_{\mathrm{T}}$ of

3897.7 , but with large temporal variations from $<7.0$ to $>8.1$. Donnarumma et al. (2014), at the

390 same $\mathrm{CO}_{2}$ seep, showed that the calcifying species tend to be less competitive as $\mathrm{pH}_{\mathrm{T}}$ decreases

391 (8.1 to 6.7) and that leaves were dominated by filamentous algae, hydroids and tunicates at the

392 lowest $\mathrm{pH}_{\mathrm{T}}$ (mean 6.7). In the laboratory, Cox et al. (2015) exposed $P$. oceanica shoots with their

393 associated epiphytes to three constant $\mathrm{pH}$ levels $\left(\mathrm{pH}_{\mathrm{T}} 8.1\right.$ ambient, 7.7 and 7.3) for four weeks.

394 Under both low $\mathrm{pH}$ treatments, there was a reduction of CCA and reduced calcification rates.

395 Similar shifts in community composition have been noted on other seagrass species as a

396 consequence of lowered pH (Burnell et al. 2014; Campbell and Fourqurean 2014; Martínez-

397 Crego et al. 2014).

398 In the present study, the epiphytic community was largely composed of CCA and

399 Bryozoa. A similar proportion of epiflora to epifauna composition on $P$. oceanica has been 
400 described in other investigations (Lepoint et al. 1999; Martin et al. 2008; Prado et al. 2008; Cox

401 et al. 2015) and coverages were similar to those reported by Cox et al. (2015) and Prado et al.

402 (2008). The decline in coverage at T4 coincides with the period of known decline of seagrass

403 biomass and leaf turnover after storm events in the autumn (Alcoverro et al. 1995).

404

CCA are often identified as having a large susceptibility to ocean acidification (Nelson

405 2009; Koch et al. 2013; Hofmann and Bischof 2014; McCoy and Kamenos 2015). CCA

406 epiphytes on P. oceanica have exhibited lowered calcification rates and coverage near and below

407 the $\mathrm{pH}_{\mathrm{T}}$ of 7.7 (Martin et al. 2008; Cox et al. 2015). Martin et al. (2008) has also demonstrated

408 their vulnerability to dissolution at $\mathrm{pH}_{\mathrm{T}}$ of 7.0 with strong undersaturation of carbonate.

409 Although some species are able to reduce carbonate demands by altering their structural

410 thickness (McCoy and Ragazzola 2014), we did not observe any visible or quantifiable alteration

411 in CCA skeletons related to $\mathrm{pH}$ manipulation, even after four months of exposure.

412 Bryozoa have also been studied in the vicinity of $\mathrm{CO}_{2}$ vents as well as in the laboratory

413 (Rodolfo-Metalpa et al. 2010; Lombardi et al. 2011b; Lombardi et al. 2011a; Smith 2014). Many

414 have an outer cuticle beneath which the mineralized skeleton forms. The protective cuticle

415 barrier and low Mg-calcite composition or ability to alter mineral composition has been used to

416 explain their persistence on leaves at volcanic $\mathrm{CO}_{2}$ seeps with a $\mathrm{pH}_{\mathrm{T}}$ as low as 6.98 (Martin et al.

417 2008; Rodolfo-Metalpa et al. 2010; Donnarumma et al. 2014). Transplant experiments, however,

418 indicate that some group members can be negatively affected (decreased thickness and signs of

419 dissolution) by ocean acidification particularly in warmer months (Rodolfo-Metalpa et al. 2010;

420 Lombardi et al. 2011b; Lombardi et al. 2011a). Therefore, it appears that the $\mathrm{pH}$ environment in

421 the experimental enclosure, even during the warmer months, was not detrimental to calcification

422 for the bulk of the community. 
It should be noted that despite rarity, Foraminifera did decline in the experimental

424 enclosure in a pattern consistent with a response to ocean acidification. This observation is in 425 agreement with 20 out of 26 studies reviewed on Foraminifera under elevated $p \mathrm{CO}_{2}$ that have 426 reported negative responses to lowered $\mathrm{pH}$ (Keul et al. 2013).

427 Recently, there have been several studies with outcomes which conflict or fail to support

428 widely-held ocean acidification projections. For example, Martin and Gattuso (2009), and

429 Egilsdottir et al. (2013) describe no clear effect of minimally lowered pH on calcifiers. Even for

430 epiphytes, Apostolaki et al. (2014) and Saderne and Wahl (2013) did not find a loss in calcified

431 coverage or reduced calcification rates at lowered $\mathrm{pH}$. The present study outcome adds to the

432 growing literature which suggests that calcified communities in their natural settings can be little

433 affected by minimal changes in surrounding carbonate chemistry.

434 There have been many speculations on the conditions that result in conflicting outcomes

435 for calcifiers under lowered $\mathrm{pH}$. Discrepancies are attributed to species specifity, other

436 environmental conditions that stress or limit organismal physiology (e.g. differences in light,

437 temperature, or combined stressors), or limitations and differences in study design (e.g. treatment

438 levels used, Kroeker et al. 2010; Koch et al. 2013; Gazeau et al. 2013).

439 Some macroalgae and benthic invertebrates are known to respond differently to $\mathrm{pH}$

440 fluctuations than they do to a mean $\mathrm{pH}$ difference (Britton et al. 2016; Small et al. 2016). The

441 median diel $\mathrm{pH}$ variation was 0.1 in the ambient meadow. The median diel $\mathrm{pH}$ range in the

442 experimental enclosure was two to three times larger than the control (0.09 to $0.29 \mathrm{pH}$ units).

443 This difference could not be explained by $\mathrm{O}_{2}$ fluxes alone and instead was attributed to lowered

444 buffering capacity of seawater with lowered $\mathrm{pH}$ (Cox et al. 2016). Because of natural $\mathrm{pH}$

445 fluctuations, it is hypothesized that organisms in seagrass meadows may already experience and 
446 be pre-adapted to $\mathrm{pH}$ levels projected into the next century (Hendriks et al. 2014a). In the present 447 study, the 0.1 diel $\mathrm{pH}$ variability in the meadow would not support possible acclimation to a $\mathrm{pH}_{\mathrm{T}}$

448 of 7.7. Productivity of coastal macrophytes can buffer the impacts of ocean acidification by

449 providing a daily window of maximum $\mathrm{CaCO}_{3}$ saturation where calcification can be more

450 efficient (Anthony et al. 2011; Anthony et al. 2013; Hendriks et al. 2014b; Cornwall et al. 2015).

451 It is possible that the $\mathrm{pH}$ offset used could have allowed for buffering at the leaf blade surface 452 and prevented CCA loss. To limit an impact, however, buffering in daylight must offset the 453 lowered $\mathrm{pH}$ that surrounds the community in the absence of photosynthesis at night. For 454 sensitive taxa the benefit of pH fluctuations appears limited (Cornwall et al. 2014; Johnson et al. 4552014 ; Roleda et al. 2015). For instance, in the laboratory recruits of coralline algae had relatively 456 lowered growth rates when $\mathrm{pH}$ fluctuated as opposed to when $\mathrm{pH}$ was constant and lowest 457 growth occurred when $\mathrm{pH}$ fluctuations were altered to mimic a future ocean acidification 458 scenario (-0.4 difference from ambient, Roleda et al. 2015). Adult coralline algae, often more 459 tolerant to ocean acidification conditions, were unaffected (Roleda et al. 2015). Congruent with 460 the reduced numbers observed in the present study with exposure to lower $\mathrm{pH}$, algal surfaces did 461 not provide refugia for foraminifera assemblages along a gradient of overlying seawater 462 acidification in Levante Bay, Italy (Pettit et al. 2015).

463 The outcome for epiphytes growing in host plant boundary layers may also depend upon 464 the $\mathrm{pH}$ scenario used. For example, recruitment and growth of calcifying serpulids and bryozoan 465 on the alga Fucus serratus were weakly to not affected at $\mathrm{pH}_{\mathrm{T}}=7.7$ but were reduced at $\mathrm{pH}_{\mathrm{T}}=$ 4667.3 (Saderne and Wahl 2013). The ocean acidification scenario used (mean $\mathrm{pH}_{\mathrm{T}}$ of 7.75 ) could 467 also explain the outcome in the present study. Maintaining a calcified skeleton presumably 468 becomes more difficult and costly as seawater gets closer to undersaturation (Kleypas et al. 
1999). Seawater in the $\mathrm{pH}$ manipulated enclosure was lower than ambient yet, it remained

470 saturated with respect to both calcite and aragonite (3.6 and 2.2). CCA have the ability to raise

471 the $\mathrm{pH}$ within their boundary layer to limit the potential negative impacts of decreased ambient

$472 \mathrm{pH}$ when seawater is not undersaturated (Hofmann et al. 2016). In contrast, at $\mathrm{CO}_{2}$ seeps, $\mathrm{pH}$

473 near the vents can be highly variable and organisms can be exposed to $\mathrm{pH}$ levels substantially

474 lower than projections for the next century (Kerrison et al. 2011). In addition, organismal

475 physiological responses can be confounded by biological conditions facilitated by venting, not

476 related to lowered $\mathrm{pH}$ (Vizzini et al. 2013).

477 Enclosures, while circulated and partly open, likely slowed water motion and could

478 possibly account for the relative increase of diatoms and provided a better refuge for calcifiers.

479 Diatoms are ubiquitous members of seagrass microepiphytic communities (Borowitzka et al.

480 2006; Mabrouk et al. 2014). Pinckeny and Fiorenza (1998) reported increased prevalence of

481 diatoms on leaves in slower flows in the Atlantic. Microalgae were also more prominent on $P$.

482 oceanica which has a greater structural canopy that can slow water movement than on

483 Cymodocea nodosa (Mabrouk et al. 2014). Slowed water flows, like those that occur in dense

484 canopies, increase boundary layer thickness surrounding plants and potentially allow for greater

485 buffering capacity in daylight (Hurd 2015) and lower buffering capacity at night. Therefore, in

486 the eFOCE experiment, the structural barrier of the enclosure may have affected the response

487 both positively and negatively. The lack of effect on epiphytes suggest that the combined

488 response was balanced.

$489 \mathrm{pH}$ effects on communities are known to be altered by seasonal factors (Burnell et al.

490 2014; Baggini et al. 2014; Martínez-Crego et al. 2014), yet in a year-long study, at an area with

491 volcanic $\mathrm{CO}_{2}$ seeps, epiphytic calcifier abundance on $P$. oceanica leaves was negatively 
492 correlated with $\mathrm{pH}$ (Donnarumma et al. 2014). In contrast, the $\mathrm{pH}$ pertubation in the present

493 study occurred during a period with large seasonal environmental change (July to November)

494 and a climax epiphytic community, and no $\mathrm{pH}$ effects were observed. We also observed, in all

495 treatments, what appeared to be a recruitment event of filamentous algae and both CCA recruits

496 (small patches) and adults with reproductive conceptacles. Thus, we surmise that if the eFOCE

497 experiment was extended for a full year the outcome would be the same. Even though this

498 experiment was conducted in a period of biomass decline, we do not think it masked an impact.

499 In other studies, a decline in CCA calcification rates and coverage has occurred rapidly (weeks to

500 months), a time frame well within the duration of study and the sampling frequency. A repeated

501 experiment with extended experimental duration is needed to clarify long-term effects and to

502 include the period of peak faunal recruitment not captured in the current study.

To the best of our knowledge, this is the only study to concurrently investigate temporal

504 changes and $\mathrm{pH}$ effects on bulk epiphytic mineralogy. The only identifiable trend for $\mathrm{Mg}$ content

505 was over time. The increase in $\mathrm{MgCO}_{3}$ after August (T2) could be explained by the seasonal

506 reduction in abundance of invertebrate calcifiers often composed of lower $\mathrm{Mg}$-calcite.

507 Alternatively, or in combination, the incorporation of more $\mathrm{Mg}$ may be due the 2 to $6{ }^{\circ} \mathrm{C}$ increase

508 (e.g. Chave and Wheeler 1965; Diaz-Pulido et al. 2014) that occurred from June to August (T0 to

$509 \sim \mathrm{T} 2)$. The presence of calcite in the epiphytes from the reference plot, compared to its absence in

510 the epiphytes sampled in the enclosures, which instead had aragonite, is at this time without

511 explanation. Similarly, the increase in calcite and aragonite that occurred at T4 is without

512 explanation. There are many reports of aragonite in CCA (Nash et al. 2011; Smith et al. 2012;

513 Diaz-Pulido et al. 2014; Krayesky-Self et al. 2016). We are not aware of any report of calcite in

514 live CCA and thus this is the first documented alteration to calcite for CCA. 
Accurate ecological projections of future oceans should arise as a consensus from

516 combined study approaches: observational, controlled laboratory, modeling, and in situ

517 experimentation. This study addressed a need for in situ $\mathrm{pH}$ manipulation to account for the

518 complexity in community response to ocean acidification. Additionally, the study design

519 accounted for natural $\mathrm{pH}$ variation that is often ignored when $\mathrm{pH}$ is manipulated in situ. While

520 large scale unreplicated experiments, like eFOCE, can provide valuable ecological information

521 they do have drawbacks (Hurlbert 1984; Oksanen 2001; Davies and Gray 2015). Replicated

522 enclosures were not feasible at this stage. Alternative hypotheses that we cannot robustly exclude

523 include (1) there were small $\mathrm{pH}$ effects difficult to quantify (2) that the conflicting outcome is

524 due to some 'lurking' variable. However, several recommended steps (Oksanen 2001; Davies

525 and Gray 2015) were taken to try to reduce erroneous conclusions that may occur including: (1)

526 care was taken to select study locations that were similar in depth and seagrass density to reduce

527 confounding variables (2) the environment was continuously monitored to ensure they were

528 similar to those in ambient, (3) repeated measurements were made at the same location through

529 time and compared to 'before' measurements when possible, (4) comparisons from the $\mathrm{pH}$

530 manipulated enclosure were made to two different spatial locations and (5) statistics used did not

531 require replication.

532 The use of a FOCE system to study the epiphytic community on $P$. oceanica leaves

533 provides a more positive outlook on the future of meadows than the projections based largely on

534 observations near $\mathrm{CO}_{2}$ vents. This conclusion should be tempered until more assessments are

535 conducted with greater replication under a variety of conditions found in meadows. Nevertheless,

536 results add to the growing evidence that calcareous members of macrophyte dominated

537 communities may be more resilient to minimal changes in carbonate chemistry. 
539 Acknowledgements We would like to acknowledge the following people who assisted in the

540 laboratory, in the field, or with engineering: E. Beck Acain, J. Acain, J. Delille, L. van der

541 Heijden, M. Maillot, F. Moullec, S. Schenone, L. Urbini, K. Walzyńska. We are grateful to A.

542 Elineau for help with the ZooScan. We also thank J.-J. Pangrazi, R. Patrix and E. Tanguy for

543 aide in construction of the enclosures. G. de Liege, D. Luquet and D. Robin kindly assisted in

544 diving collection activities. This work was funded by the 'European Free Ocean Carbon

545 Enrichment' (eFOCE; BNP-Paribas Foundation), the 'European Project on Ocean Acidification'

546 (EPOCA; grant agreement 211384) and the MISTRALS-MERMEX (INSU, CNRS) program.

548 Ethical Statement

549 The authors declare that they have no conflict of interests and all applicable guidelines for the 550 use of animals were followed. 
References

552

553

554

555

556

557

558

559

560

561

562

563

564

565

566

567

568

569

570

571

572

573

574

575

576

577

578

579

580

581

582

583

584

Alcoverro T, Duarte C, Romero J (1995) Annual growth dynamics of Posidonia oceanica: contribution of large-scale versus local factors to seasonality. Mar Ecol Prog Ser 120:203-210. doi: 10.3354/meps120203

Anthony KRN, Diaz-Pulido G, Verlinden N, Tilbrook B, Andersson AJ (2013) Benthic buffers and boosters of ocean acidification on coral reefs. Biogeosciences 10:4897-4909. doi: $10.5194 /$ bg-10-4897-2013

Anthony KRN, Kleypas J, Gattuso J-P (2011) Coral reefs modify their seawater carbon chemistry - implications for impacts of ocean acidification. Global Change Biol 17:36553666. doi: 10.1111/j.1365-2486.2011.02510.x

Apostolaki ET, Vizzini S, Hendriks IE, Olsen YS (2014) Seagrass ecosystem response to longterm high $\mathrm{CO}_{2}$ in a Mediterranean volcanic vent. Mar Environ Res 99:9-15

Baggini C, Salomidi M, Voutsinas E, Bray L, Krasakopoulou E, Hall-Spencer JM (2014) Seasonality affects macroalgal community response to increases in $p \mathrm{CO}_{2}$. PLoS ONE 9:e106520. doi: 10.1371/journal.pone. 0106520

Beer S, Koch E (1996) Photosynthesis of marine macroalgae and seagrasses in globally changing $\mathrm{CO}_{2}$ environments. Mar Ecol Prog Ser 141:199-204

Borowitzka MA, Lavery PS, van Keulen M (2006) Seagrasses: Biology, Ecology and Conservation. In: Larkum AWD, Orth RJ, Duarte CM (eds) Epiphytes of seagrasses. Springer, Dordrecht, The Netherlands, pp 441-461

Bosence D (1989) Biogenic carbonate production in Florida Bay. Bull Mar Sci 44:419-433

Britton D, Cornwall CE, Revill AT, Hurd C, Johnson C (2016) Ocean acidification reverses the positive effects of seawater $\mathrm{pH}$ fluctuations on growth and photosynthesis of the habitatforming kelp, Ecklonia radiata. Sci Rep. doi: 10.1038/srep26036

Burnell O, Russell B, Irving A, Connell S (2014) Seagrass response to $\mathrm{CO}_{2}$ contingent on epiphytic algae: indirect effects can overwhelm direct effects. Oecologia 176:871-882

Campbell JE, Fourqurean JW (2014) Ocean acidification outweighs nutrient effects in structuring seagrass epiphyte communities. J Ecol 102:730-737. doi: 10.1111/13652745.12233

Cebrián J, Enríquez S, Fortes MD, Agawin N, Vermaat JE, Duarte CM (1999) Epiphyte accrual on Posidonia oceanica (L.) Delile leaves: Implications for light absorption. Bot Mar 42:123-128. doi: 10.1515/BOT.1999.015

Chave KE, Wheeler BD (1965) Mineralogic changes during growth in the red alga, Clathromorphum compactum. Science 147:621-621. doi: 10.1126/science.147.3658.621 
Ciais P, Sabine C, Bala G, Bopp L, Brovkin V, Canadell J, Chhabra A, DeFries R, Galloway J, Heimann M, Jones C, Le Quéré C, Myneni RB, Piao S, Thornton P (2013) Carbon and other biogeochemical cycles. Cambridge University Press, Cambridge, United Kingdom and New York, NY, USA

Clarke KR (1993) Non-parametric multivariate analyses of changes in community structure. Austral Ecol 18:117-143. doi: 10.1111/j.1442-9993.1993.tb00438.x

Cornwall C, Pilditch C, Hepburn C, Hurd CL (2015) Canopy macroalgae influence understorey corallines' metabolic control of near-surface $\mathrm{pH}$ and oxygen concentration. Mar Ecol Prog Ser 525:81-95. doi: 10.3354/meps11190

Cornwall CE, Boyd PW, McGraw CM, Hepburn C, Pilditch CA, Morris JN, Smith AM, Hurd CL (2014) Diffusion boundary layers ameliorate the negative effects of ocean acidification on the temperate coralline macroalga Arthrocardia corymbosa. PLoS ONE 9:e97235. doi: 10.1371/journal.pone.0097235

Cox TE, Gazeau F, Alliouane S, Hendriks IE, Mahacek P, Le Fur A, Gattuso J-P (2016) Effects of in situ $\mathrm{CO}_{2}$ enrichment on structural characteristics, photosynthesis, and growth of the Mediterranean seagrass Posidonia oceanica . Biogeosciences 13:2179-2194. doi: $10.5194 /$ bg-13-2179-2016

Cox TE, Schenone S, Delille J, Díaz-Castañeda V, Alliouane S, Gattuso JP, Gazeau F (2015) Effects of ocean acidification on Posidonia oceanica epiphytic community and shoot productivity. J Ecol 103:1594-1609. doi: 10.1111/1365-2745.12477

Davies GM, Gray A (2015) Don't let spurious accusations of pseudoreplication limit our ability to learn from natural experiments (and other messy kinds of ecological monitoring). Ecol Evol 5:5295-5304. doi: 10.1002/ece3.1782

Diaz-Pulido G, Nash MC, Anthony KRN, Bender D, Opdyke BN, Reyes-Nivia C, Troitzsch U (2014) Greenhouse conditions induce mineralogical changes and dolomite accumulation in coralline algae on tropical reefs. Nature Comm. doi: 10.1038/ncomms4310

Donnarumma L, Lombardi C, Cocito S, Gambi MC (2014) Settlement pattern of Posidonia oceanica epibionts along a gradient of ocean acidification : an approach with mimics. Mediterr Mar Sci 15:498-509. doi: 10.12681/mms.677

Egilsdottir H, Noisette F, Noël LM-LJ, Olafsson J, Martin S (2013) Effects of $p \mathrm{CO}_{2}$ on physiology and skeletal mineralogy in a tidal pool coralline alga Corallina elongata. Mar Biol 160:2103-2112. doi: 10.1007/s00227-012-2090-7

Fabry VJ, Seibel BA, Feely RA, Orr JC (2008) Impacts of ocean acidification on marine fauna and ecosystem processes. ICES J Mar Sci 65:414-432. doi: 10.1093/icesjms/fsn048

Feely RA (2004) Impact of anthropogenic $\mathrm{CO}_{2}$ on the $\mathrm{CaCO}_{3}$ system in the oceans. Science 305:362-366. doi: 10.1126/science.1097329 
Frankovich TA, Zieman JC (1994) Total epiphyte and epiphytic carbonate production on Thalassia testudinum across Florida Bay. Bull Mar Sci 54:679-695.

Gattuso J-P, Kirkwood W, Barry JP, Cox TE, Gazeau F, Hansson L, Hendriks I, Kline DI, Mahacek P, Martin S, McElhany P, Peltzer ET, Reeve J, Roberts D, Saderne V, Tait K, Widdicombe S, Brewer PG (2014) Free-ocean $\mathrm{CO}_{2}$ enrichment (FOCE) systems: present status and future developments. Biogeosciences 11:4057-4075.

Gattuso J-P, Magnan A, Bille R, Cheung WWL, Howes EL, Joos F, Allemand D, Bopp L, Cooley SR, Eakin CM, Hoegh-Guldberg O, Kelly RP, Portner H-O, Rogers AD, Baxter JM, Laffoley D, Osborn D, Rankovic A, Rochette J, Sumaila UR, Treyer S, Turley C (2015) Contrasting futures for ocean and society from different anthropogenic $\mathrm{CO}_{2}$ emissions scenarios. Science 349:aac4722-aac4722. doi: 10.1126/science.aac4722

Gaylord B, Kroeker KJ, Sunday JM, Anderson KM, Barry JP, Brown NE, Connell SD, Dupont S, Fabricius KE, Hall-Spencer JM, Klinger T, Milazzo M, Munday PL, Russell BD, Sanford E, Schreiber SJ, Thiyagarajan V, Vaughan MLH, Widdicombe S, Harley CDG (2015) Ocean acidification through the lens of ecological theory. Ecology 96:3-15. doi: $10.1890 / 14-0802.1$

Gazeau F, Parker LM, Comeau S, Gattuso J-P, O’Connor WA, Martin S, Pörtner H-O, Ross PM (2013) Impacts of ocean acidification on marine shelled molluscs. Mar Biol 160:22072245. doi: 10.1007/s00227-013-2219-3

Gischler E, Dietrich S, Harris D, Webster JM, Ginsburg RN (2013) A comparative study of modern carbonate mud in reefs and carbonate platforms: Mostly biogenic, some precipitated. Sediment Geol 292:36-55. doi: 10.1016/j.sedgeo.2013.04.003

Gorsky G, Ohman MD, Picheral M, Gasparini S, Stemmann L, Romagnan JB, Cawood A, Pesant S, Garcia-Comas C, Prejger F (2010) Digital zooplankton image analysis using the ZooScan integrated system. J Plankton Res 32:285-303.

Hall-Spencer JM, Rodolfo-Metalpa R, Martin S, E, Fine M, Turner SM, Rowley SJ, Tedesco D, Buia MC (2008) Volcanic carbon dioxide vents show ecosystem effects of ocean acidification. Nature 454:96-99

Hemminga MA, Duarte CM (2000) Seagrass Ecology. University of Cambridge, Cambridge, United Kingdom

Hendriks IE, Duarte CM, Olsen YS, Steckbauer A, Ramajo L, Moore TS, Trotter JA, McCulloch M (2014a) Biological mechanisms supporting adaptation to ocean acidification in coastal ecosystems. Estuar Coast Shelf Sci 152:1-8. doi: 10.1016/j.ecss.2014.07.019

Hendriks IE, Olsen YS, Ramajo L, Basso L, Steckbauer A, Moore TS, Howard J, Duarte CM (2014b) Photosynthetic activity buffers ocean acidification in seagrass meadows. Biogeosciences 11:333-346. doi: 10.5194/bg-11-333-2014 
Hofmann LC, Bischof K (2014) Ocean acidification effects on calcifying macroalgae. Aquat Biol 22:261-279

Hofmann LC, Koch M, de Beer D (2016) Biotic control of surface $\mathrm{pH}$ and evidence of lightinduced $\mathrm{H}+$ pumping and $\mathrm{Ca}^{2+}-\mathrm{H}^{+}$exchange in a tropical crustose coralline alga. PloS ONE 11: $\mathrm{e} 0159057$

Hurd CL (2015) Slow-flow habitats as refugia for coastal calcifiers from ocean acidification. J Phycol 51:599-605. doi: 10.1111/jpy.12307

Hurlbert S (1984) Pseudoreplication and the design of ecological field experiments. Ecol Monogr 187-211

Jackson EL, Rees SE, Wilding C, Attrill MJ (2015) Use of a seagrass residency index to apportion commercial fishery landing values and recreation fisheries expenditure to seagrass habitat service: Seagrass contribution to fishery value. Cons Biol 29:899-909. doi: 10.1111/cobi.12436

Johnson MD, Moriarty VW, Carpenter RC (2014) Acclimatization of the crustose coralline alga Porolithon onkodes to variable $p \mathrm{CO}_{2}$. PLoS ONE 9:e87678. doi: 10.1371/journal.pone.0087678

Kerrison P, Hall-Spencer JM, Suggett DJ, Hepburn LJ, Steinke M (2011) Assessment of pH variability at a coastal $\mathrm{CO}_{2}$ vent for ocean acidification studies. Estuar Coast Shelf Sci 94:129-137

Keul N, Langer G, de Nooijer LJ, Bijma J (2013) Effect of ocean acidification on the benthic foraminifera Ammonia sp. is caused by a decrease in carbonate ion concentration. Biogeosciences 10:6185-6198. doi: 10.5194/bg-10-6185-2013

Kleypas J, Buddemeier R, Archer D, Gattuso J-P, Langdon C, Opdyke, B (1999) Geochemical consequences of increased atmospheric carbon dioxide on coral reefs. Science 284:118120.

Koch M, Bowes G, Ross C, Zhang XH (2013) Climate change and ocean acidification effects on seagrasses and marine macroalgae. Glob Change Biol 19:103-132. doi: 10.1111/j.13652486.2012.02791.x

Krayesky-Self S, Richards JL, Rahmatian M, Fredericq S (2016) Aragonite infill in overgrown conceptacles of coralline Lithothamnion spp. (Hapalidiaceae, Hapalidiales, Rhodophyta): new insights in biomineralization and phylomineralogy. J Phycol 52:161-173. doi: 10.1111/jpy.12392

Kroeker KJ, Kordas RL, Crim R, Singh GG (2013) Impacts of ocean acidification on marine organisms: quantifying sensitivities and interaction with warming. Glob Change Biol 19:1884-1896. doi: $10.1111 / \mathrm{gcb} .12179$ 
692

693

694

695

696

697

698

699

700

701

702

703

704

705

706

707

708

709

710

711

712

713

714

715

716

717

718

719

720

721

722

723

724

725

726

Kroeker KJ, Kordas RL, Crim RN, Singh GG, Hendriks IE, Ramajo L, Singh GS, Duarte CM, Gattuso J-P (2010) Meta-analysis reveals negative yet variable effects of ocean acidification on marine organisms: Biological responses to ocean acidification. Ecol Lett 13:1419-1434. doi: 10.1111/j.1461-0248.2010.01518.x

Kroeker KJ, Micheli F, Gambi MC (2012) Ocean acidification causes ecosystem shifts via altered competitive interactions. Nat Clim Change 3:156-159. doi: 10.1038/nclimate1680

Land LS (1970) Carbonate mud: production by epibiont growth on Thalassia testudinum. J Sediment Petrol 40:1361-1363

Lepoint G, Havelange S, Gobert S, Bouquegneau JM (1999) Fauna vs flora contribution to the leaf epiphytes biomass in a Posidonia oceanica seagrass bed (Revellata Bay, Corsica). Hydrobiologia 394:63-67

Lepoint G, Jacquemart J, Bouquegneau JM, Demoulin V, Gobert S (2007) Field measurements of inorganic nitrogen uptake by epiflora components of the seagrass Posidonia oceanica (Monocotyledons, Posidoniaceae). J Phycol 43:208-218

Lepoint G, Nyssen F, Gobert S, Dauby P, Bouquegneau JM (2000) Relative impact of a seagrass bed and its adjacent epilithic algal community in consumer diets. Mar Biol 136:513-518

Littler M, Littler D (2013) The nature of crustose coralline algae and their interactions on reefs. Smithson Contrib Mar Sci 39:199-212

Lombardi C, Cocito S, Gambi M, Cisterna B, Flach F, Taylor P, Keltie K, Freer A, Cusack M (2011a) Effects of ocean acidification on growth, organic tissue and protein profile of the Mediterranean -bryozoan Myriapora truncata. Aquat Biol 13:251-262. doi: $10.3354 / \mathrm{ab} 00376$

Lombardi C, Gambi MC, Vasapollo C, Taylor P, Cocito S (2011b) Skeletal alterations and polymorphism in a Mediterranean bryozoan at natural $\mathrm{CO}_{2}$ vents. Zoomorphology 130:135-145. doi: 10.1007/s00435-011-0127-y

Mabrouk L, Ben Brahim M, Hamza A, Mahfoudhi M, Bradai MN (2014) A comparison of abundance and diversity of epiphytic microalgal assemblages on the leaves of the seagrasses Posidonia oceanica (L.) and Cymodocea nodosa (Ucria) Asch in Eastern Tunisia. J Mar Biol 2014:1-10. doi: 10.1155/2014/275305

Martin S, Gattuso J-P (2009) Response of Mediterranean coralline algae to ocean acidification and elevated temperature. Glob Change Biol 15:2089-2100. doi: 10.1111/j.13652486.2009.01874.x

Martin S, Rodolfo-Metalpa R, Ransome E, Rowley S, Buia M-CC, Gattuso J-P, Hall-Spencer J (2008) Effects of naturally acidified seawater on seagrass calcareous epibionts. Biol Lett 4:689-692. doi: 10.1098/rsbl.2008.0412 
Martínez-Crego B, Olivé I, Santos R (2014) $\mathrm{CO}_{2}$ and nutrient-driven changes across multiple levels of organization in Zostera noltii ecosystems. Biogeosciences 11:7237-7249

McCoy SJ, Kamenos NA (2015) Coralline algae (Rhodophyta) in a changing world: integrating ecological, physiological, and geochemical responses to global change. J Phycol 51:6-24 doi: $10.1111 /$ jpy. 12262

McCoy SJ, Ragazzola F (2014) Skeletal trade-offs in coralline algae in response to ocean acidification. Nat Clim Change 4:719-723. doi: 10.1038/nclimate2273

Nash MC, Opdyke BN, Wu Z, Xu H, Trafford JM (2014) Simple X-Ray diffraction techniques to identify $\mathrm{Mg}$-calcite, dolomite, and magnesite in tropical coralline algae and assess peak asymmetry. J Sediment Res 83:1084-1098. doi: 10.2110/jsr.2013.67

Nash MC, Troitzsch U, Opdyke BN, Trafford JM, Russell BD, Kline DI (2011) First discovery of dolomite and magnesite in living coralline algae and its geobiological implications. Biogeosciences 8:3331-3340. doi: 10.5194/bg-8-3331-2011

Nelsen JE, Ginsburg RN (1986) Calcium carbonate production by epibionts on Thalassia in Florida Bay. J Sediment Res Vol. 56:622-628. doi: 10.1306/212F89EF-2B24-11D7$8648000102 \mathrm{C} 1865 \mathrm{D}$

Nelson W (2009) Calcified macroalgae-critical to coastal ecosystems and vulnerable to change: a review. Mar Freshwater Res 60:787-801. doi: 10.1071/MF08335

Oksanen L (2001) Logic of experiments in ecology: is pseudoreplication a pseudoissue? Oikos 94:27-38. doi: 10.1034/j.1600-0706.2001.11311.x

Pasqualini V, Pergent-Martini C, Clabaut P, Pergent G (1998) Mapping of Posidonia oceanica using aerial photographs and side scan sonar: application off the island of Corsica (France). Estuar Coast Shelf Sci 47:359-367

Perry CT, Beavington-Penney SJ (2005) Epiphytic calcium carbonate production and facies development within sub-tropical seagrass beds, Inhaca Island, Mozambique. Sediment Geol 174:161-176. doi: 10.1016/j.sedgeo.2004.12.003

Pettit LR, Smart CW, Hart MB, Milazzo M, Hall-Spencer JM (2015) Seaweed fails to prevent ocean acidification impact on foraminifera along a shallow-water $\mathrm{CO}_{2}$ gradient. Ecol Evol 5:1784-1793. doi: 10.1002/ece3.1475

Pinckney JL, Fiorenza M (1998) Microalgae on seagrass mimics: Does epiphyte community structure differ from live seagrasses? J Exp Mar Biol Ecol 221:59-70

Prado P, Alcoverro T, Romero J (2008) Seasonal response of Posidonia oceanica epiphyte assemblages to nutrient increase. Mar Ecol Prog Ser 359:89-98 
Rodolfo-Metalpa R, Lombardi C, Cocito S, Hall-Spencer JM, Gambi MC (2010) Effects of ocean acidification and high temperatures on the bryozoan Myriapora truncata at natural $\mathrm{CO}_{2}$ vents. Mar Ecol 31:447-456. doi: 10.1111/j.1439-0485.2009.00354.x

Roleda MY, Cornwall CE, Feng Y, McGraw CM, Smith AM, Hurd CL (2015) Effect of ocean acidification and $\mathrm{pH}$ Fluctuations on the growth and development of coralline algal recruits, and an associated benthic algal assemblage. PLOS ONE 10:e0140394. doi: 10.1371/journal.pone.0140394

Saderne V, Wahl M (2013) Differential responses of calcifying and non- calcifying epibionts of a brown macroalga to present-day and future upwelling $p \mathrm{CO}_{2}$. PLoS ONE 8:e70455. doi: 10.1371/journal.pone.0070455

Small DP, Milazzo M, Bertolini C, Graham H, Hauton C, Hall-Spencer JM, Rastrick SPS (2016) Temporal fluctuations in seawater $p \mathrm{CO}_{2}$ may be as important as mean differences when determining physiological sensitivity in natural systems. ICES J Mar Sci 73:604-612. doi: 10.1093/icesjms/fsv232

Smith AM (2014) Growth and calcification of marine bryozoans in a changing ocean. Biol Bull 226:203-210

Smith AM, Sutherland JE, Kregting L, Farr TJ, Winter DJ (2012) Phylomineralogy of the coralline red algae: Correlation of skeletal mineralogy with molecular phylogeny. Phytochemistry 81:97-108. doi: 10.1016/j.phytochem.2012.06.003

Steel JB, Wilson BJ (2003) Which is the phyte in epiphyte? Folia Geobotanica 38:97-99. doi: 10.1007/BF02803129

Stewart-Oaten A, Murdoch W, Parker K (1986) Environmental impact assessment: "Pseudoreplication" in time? Ecol 67:929-940

Sunday JM, Fabricius KE, Kroeker KJ, Anderson KM, Brown NE, Barry JP, Connell SD, Dupont S, Gaylord B, Hall-Spencer JM, Klinger T, Milazzo M, Munday PL, Russell BD, Sanford E, Thiyagarajan V, Vaughan MLH, Widdicombe S, Harley CDG (2016) Ocean acidification can mediate biodiversity shifts by changing biogenic habitat. Nat Clim Change 7:81-85. doi: 10.1038/nclimate3161

Tomas F, Turon X, Romero J (2005) Effects of herbivores on a Posidonia oceanica seagrass meadow: importance of epiphytes. Mar Ecol Prog Ser 287:115-125

Vizzini S, Di Leonardo R, Costa V, Tramati CD, Luzzu F, Mazzola A (2013) Trace element bias in the use of $\mathrm{CO}_{2}$ vents as analogues for low $\mathrm{pH}$ environments: implications for contamination levels in acidified oceans. Estuar Coast Shelf Sci 134:19-30. doi: 10.1016/j.ecss.2013.09.015 


\section{Figure captions}

Fig. 1 nMDS based upon the Bray-Curtis Index of dissimilarity for the epiphytic community within the reference plot, control and experimental enclosure (represented by symbols) at each sampling interval, labeled 1 to 4 for T1 to T4 which corresponds to 0 , 39, 74, 109, $135 \mathrm{~d}$ after the $\mathrm{pH}$ manipulation in the months of June, July, September, October and November respectively

Fig. 2 A - G are boxplots showing the minimum, maximum, mean (dotted line) and median (solid line) coverage (\%) of each epiphytic taxonomic or functional unit as occurred on leaves ( $\mathrm{N}=3$ to 7 ) collected from the ambient (sampled 1x, T0), reference plot (ambient environment, T1 to T4) and two enclosures (control and experimental) at sampling intervals T0 to T4 (intervals correspond to $0,39,74,109,135 \mathrm{~d}$ after the $\mathrm{pH}$ manipulation in the months of June, July, September, October and November, respectively)

Fig. 3 Boxplots showing the minimum, maximum, mean (dotted line) and median (solid line) epiphytic total and calcareous organism coverage (\%) as well as calcium carbonate $\left(\mathrm{CaCO}_{3}\right)$ mass $\left(\mathrm{mg} \mathrm{cm}{ }^{-2}, \mathrm{~N}=3\right.$ to 7 leaves) in the ambient (sampled $\left.1 \mathrm{x}, \mathrm{T} 0\right)$, reference plot (ambient environment, T1 to T4) and two enclosures (control and experimental) at sampling intervals T0 to T4 (See Fig.1 for additional details on intervals)

Fig. 4 Results from XRD with principles of peak asymmetry show, for each sample, the mol \% magnesium in carbonate for the bulk epiphytes in the ambient (location sampled 
1x, T0), reference plot (ambient environment, T1 to T4) and two enclosures (control and experimental) at sampling intervals $\mathrm{T} 0$ to $\mathrm{T} 4(\mathrm{~N}=3$ leaves, see Fig. 1 for additional details on intervals). The relative calcite asymmetry is shown in panel B; values were not quantified. Aragonite (C) was determined from the area under the curve

Fig. 5 SEM-EDS images of typical cell wall calcification of epiphytic crustose coralline algae (CCA) as observed in enclosures (control and $\mathrm{pH}$-manipulated experimental) and ambient environment (T0 and reference plot) throughout the duration of study. Images A and B show crustose coralline algae on the leaf. B is a closer view of the outlined area where $\mathrm{Mg}$-calcite $(\mathrm{Mg}-\mathrm{C})$ grains were observed. $\mathrm{C}$ and D show the crustose coralline cell walls and interfilaments engrained with $\mathrm{Mg}$-calcite crystals

Fig. 6 SEM-EDS images of alteration of mineral composition in epiphytic crustose coralline algae as occurred on leaves from the ambient environment (T0 and reference plot) and two enclosures (control and $\mathrm{pH}$-manipulated experimental). A-C (left) demonstrate mineral alteration between $\mathrm{Mg}$-calcite $(\mathrm{Mg}-\mathrm{C})$ and calcite (abbreviated as $\mathrm{C}$ ) which occurred in the ambient environment. A shows the location of calcite (white outline) and Mg-calcite. In closer view of the altered area (B and C) calcite grains can be observed. D-E demonstrates alteration from Mg-calcite to aragonite which occurred in the enclosures. $\mathrm{D}$ is an image of crustose coralline algae on the leaf surface showing altered patches where aragonite occurred; in closer view (E and F) the altered surfaces lacked cell wall features and clear crystal shape 


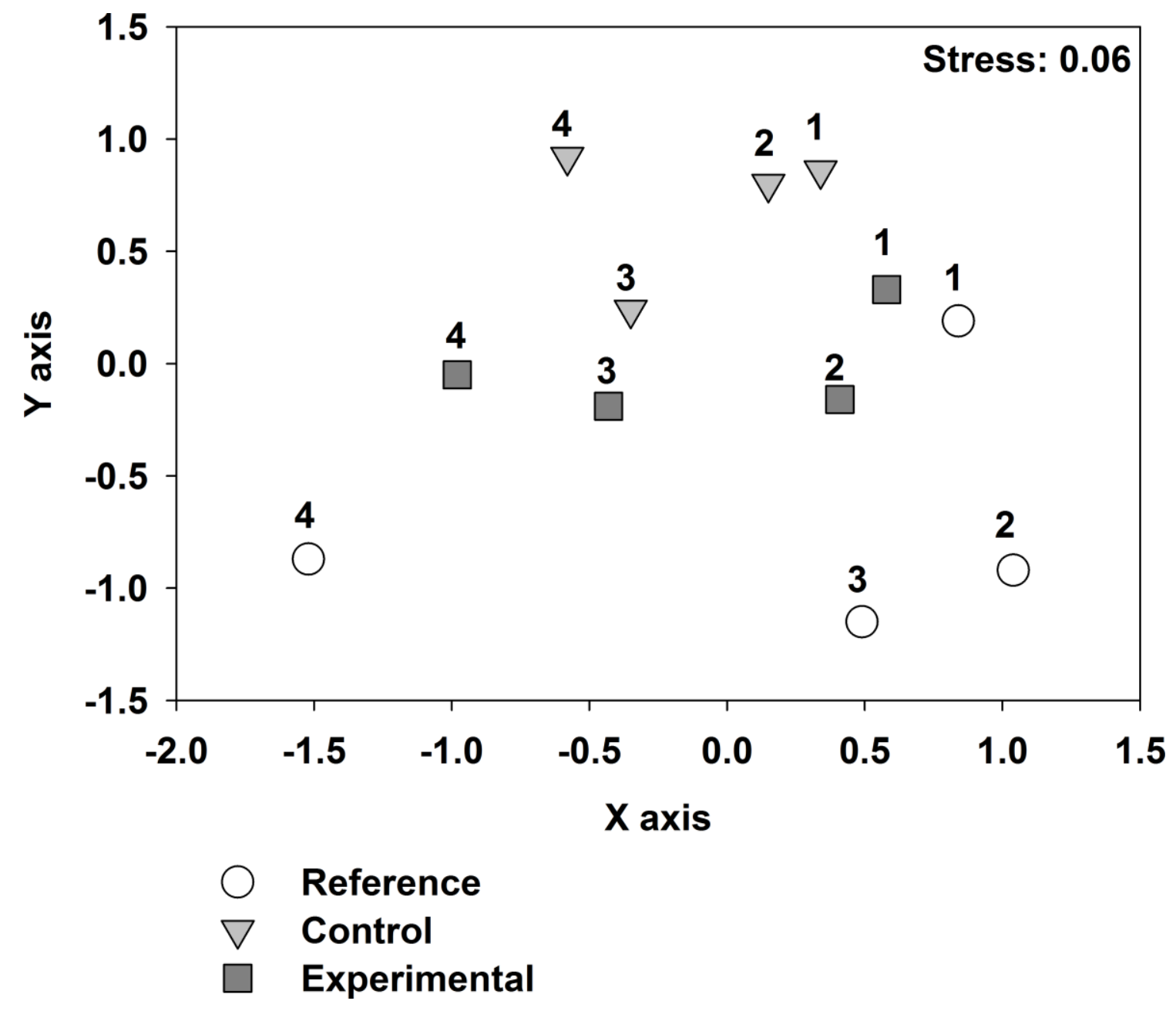




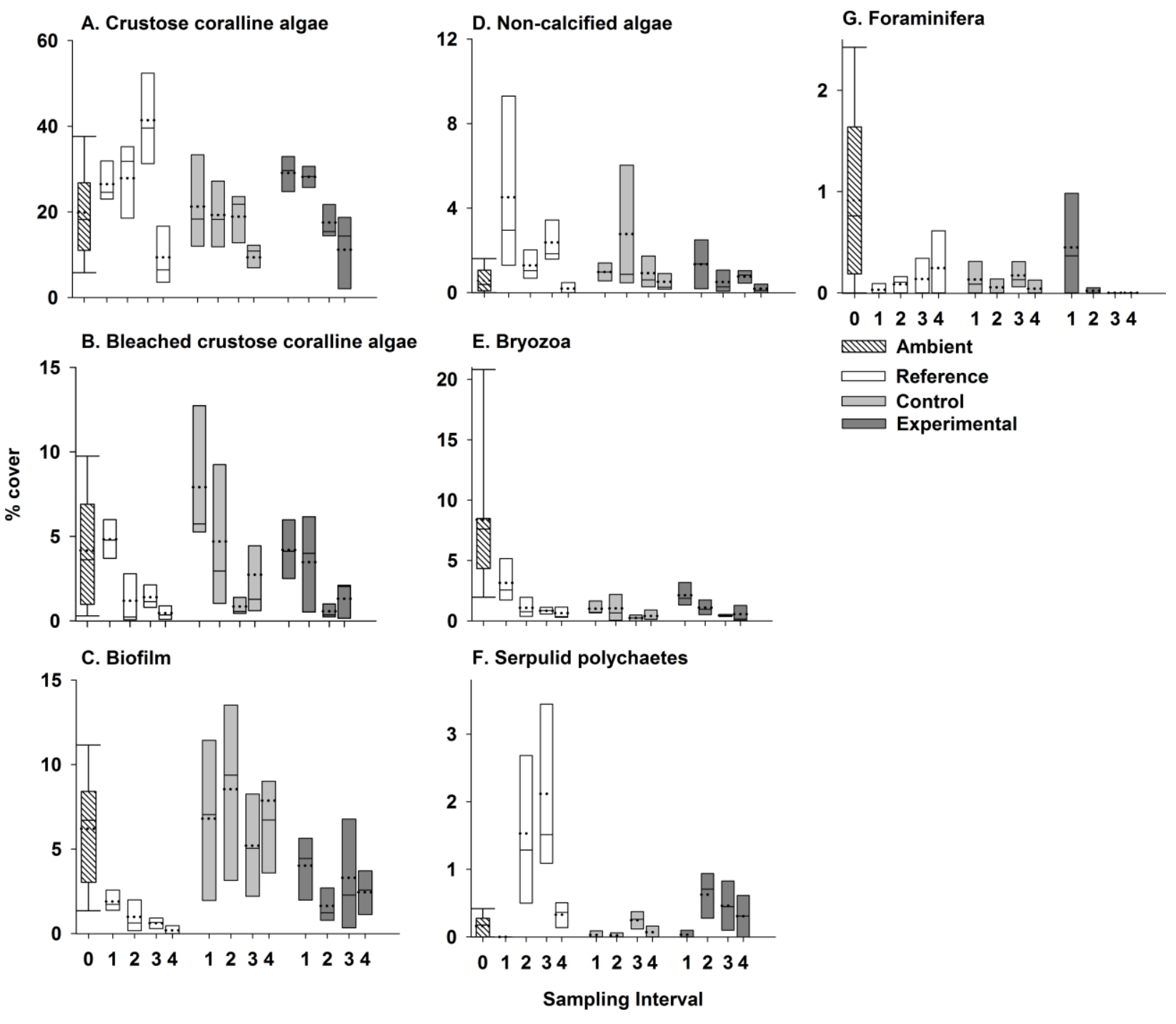




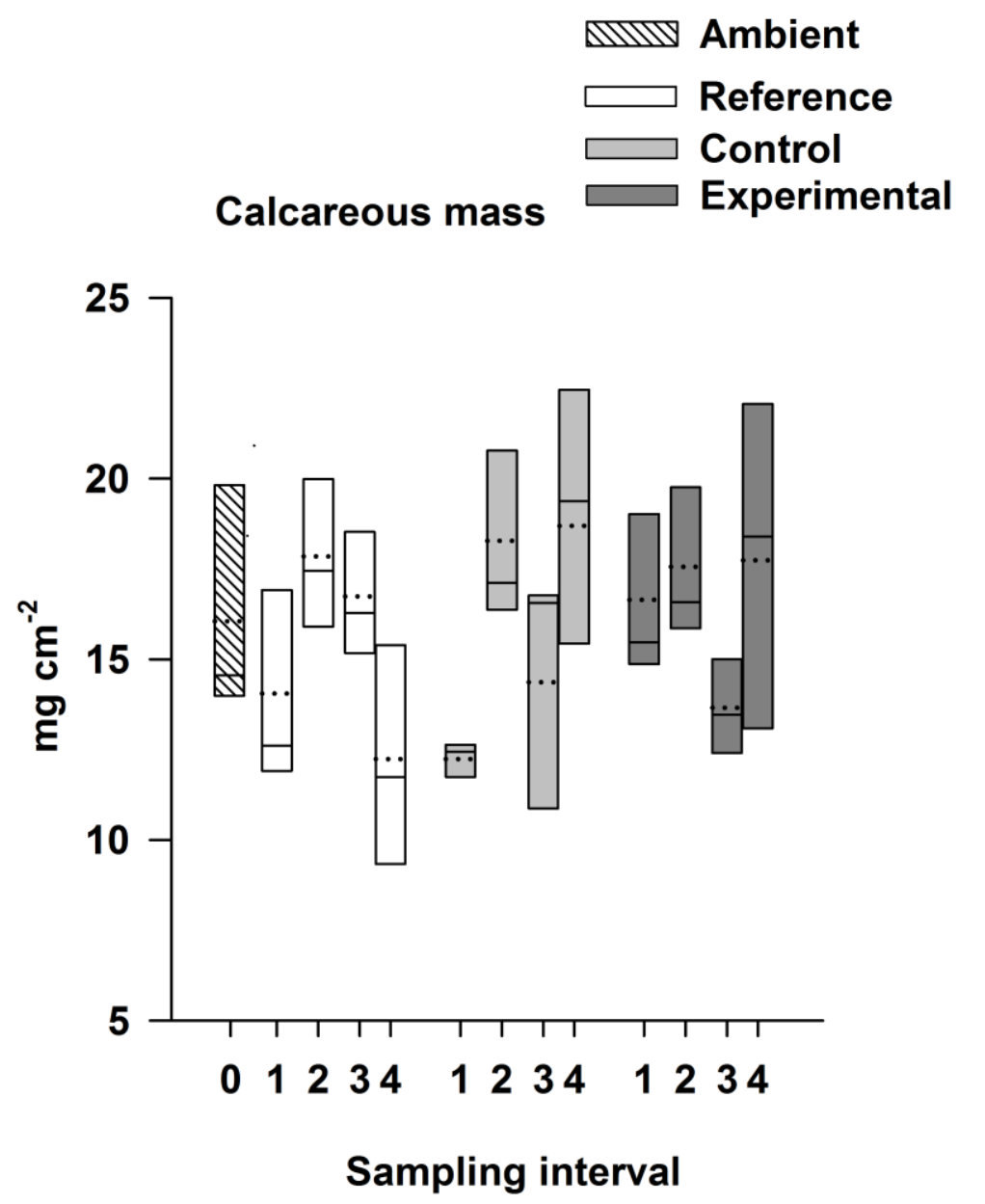




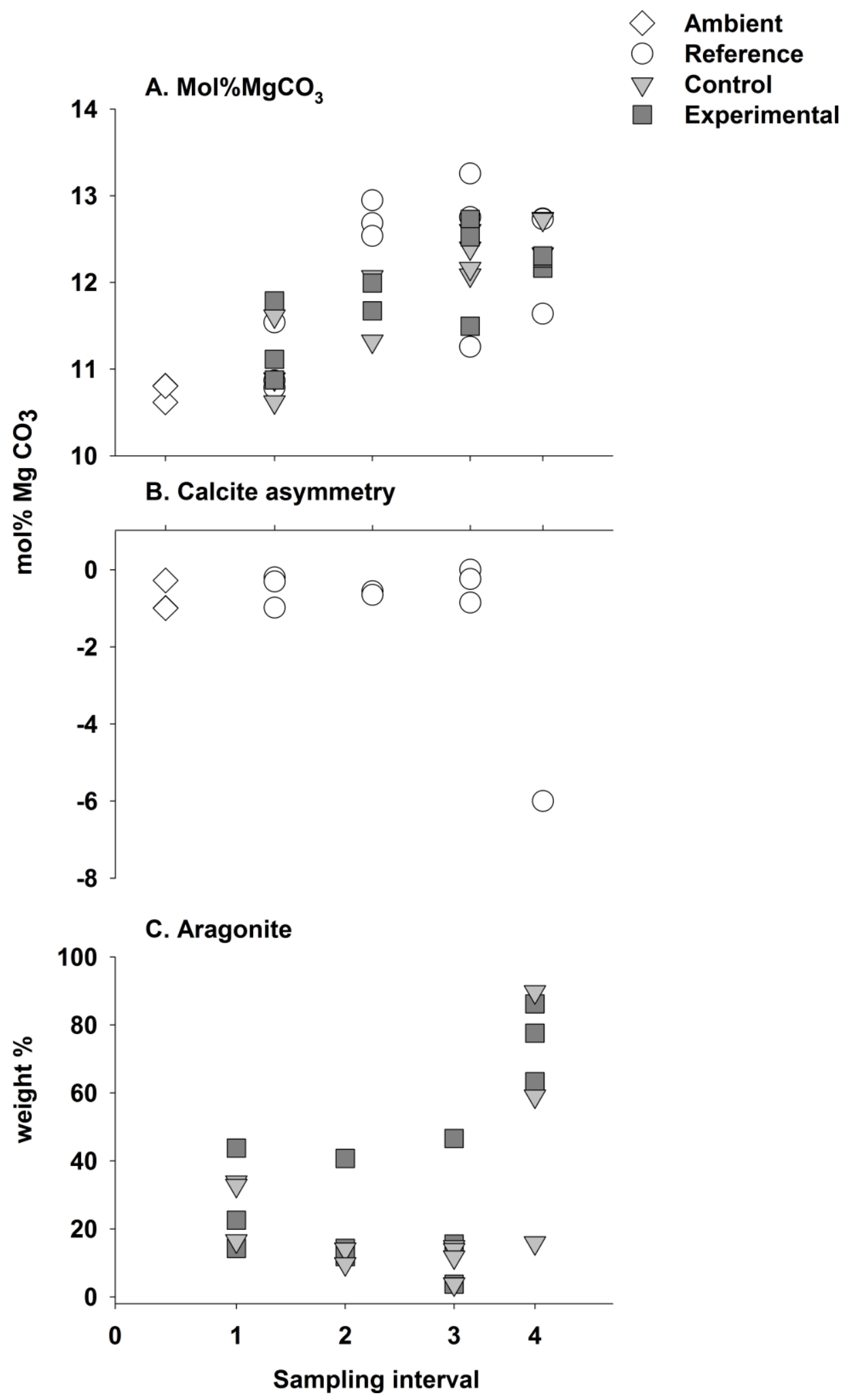




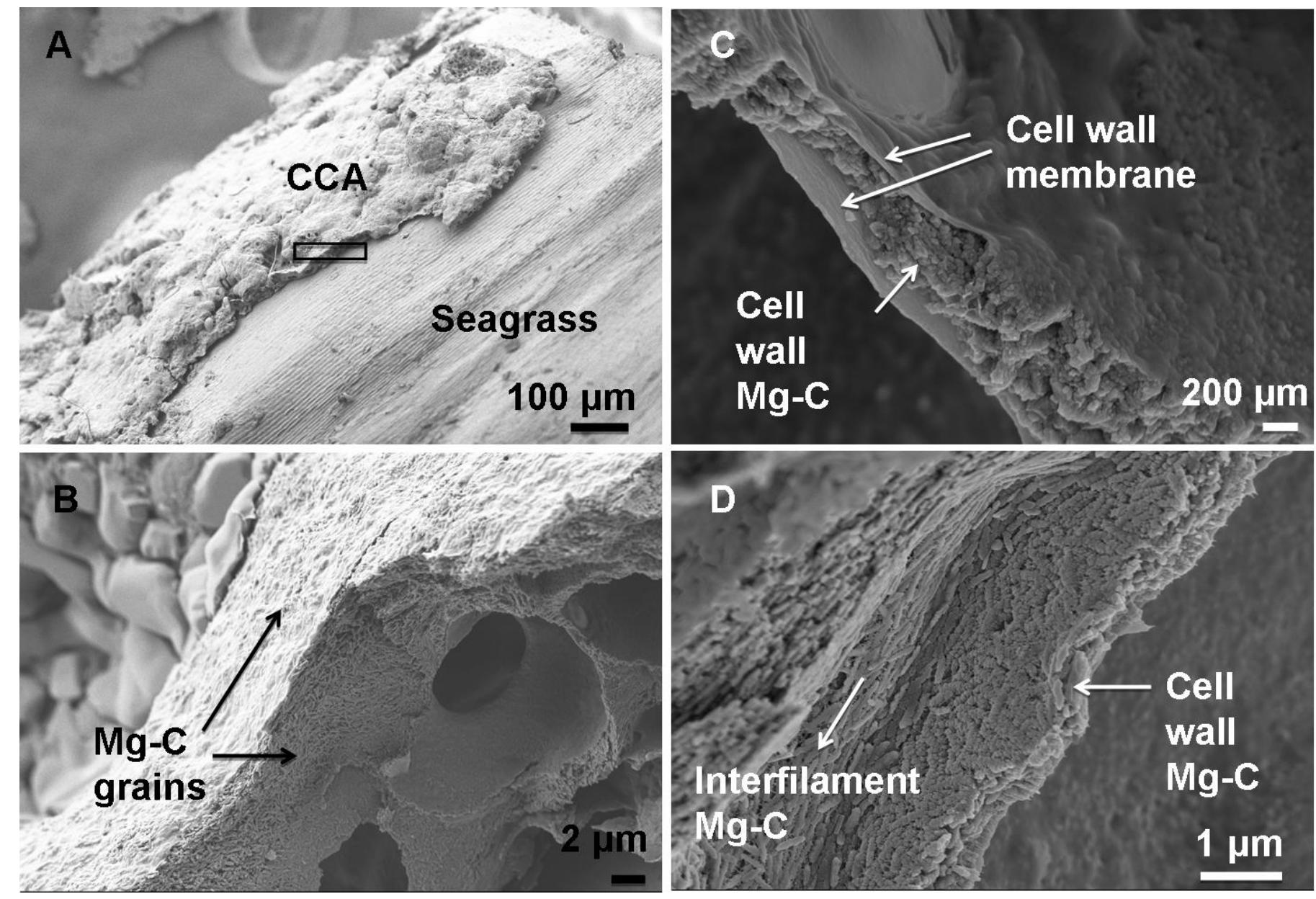



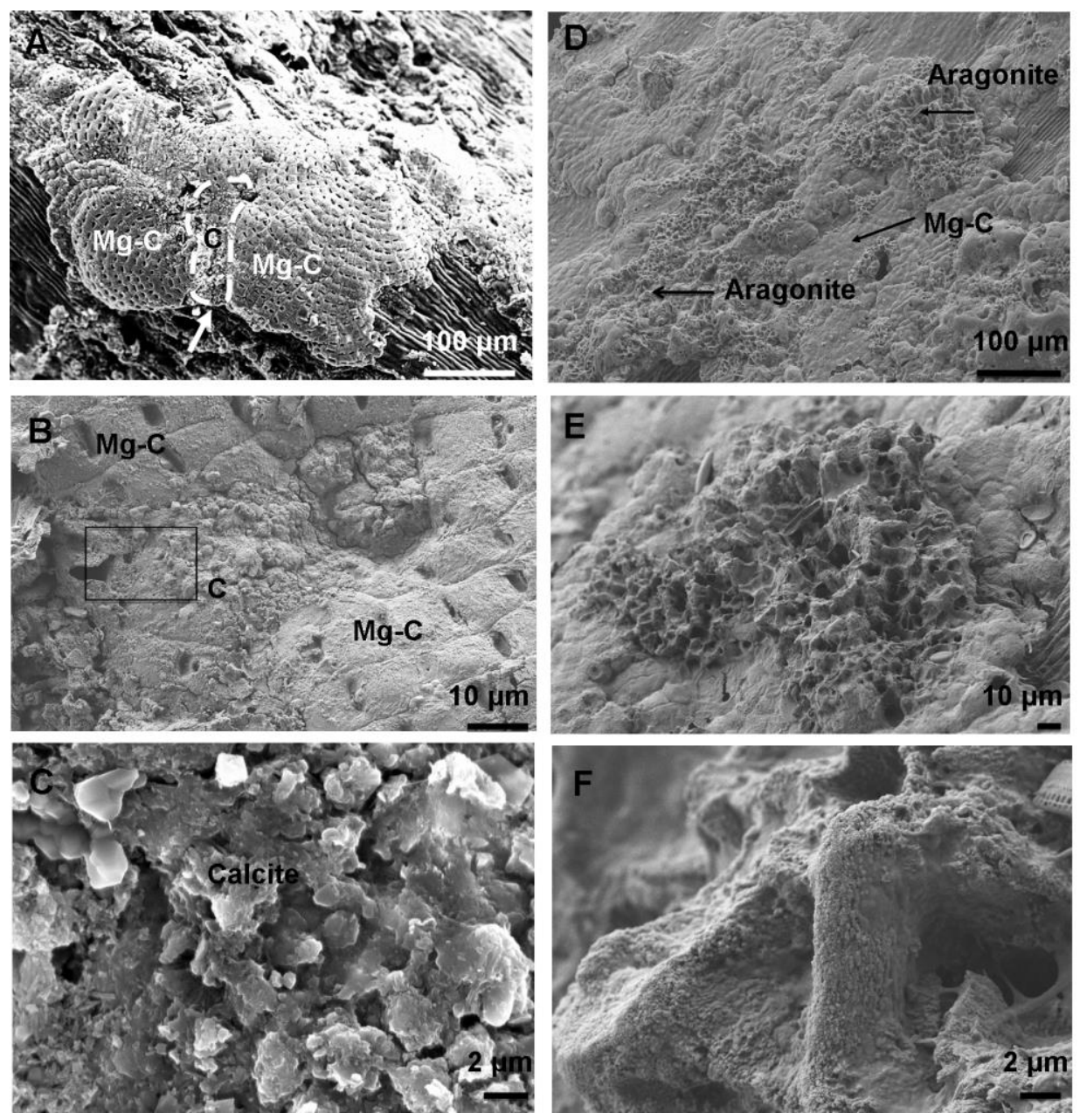
Table 1. Carbonate chemistry within ambient and enclosures: mean ( \pm standard deviation, $\mathrm{SD}) \mathrm{pH}$ (on the total scale; $\left.\mathrm{pH}_{\mathrm{T}}\right)$, partial pressure of carbon dioxide $\left(p \mathrm{CO}_{2}\right)$ and saturation states with respect to aragonite $\left(\Omega_{\mathrm{a}}\right)$ and calcite $\left(\Omega_{\mathrm{a}}\right)$ for each month and the period before and during acidification. The difference in $\mathrm{pH}_{\mathrm{T}}$ between the experimental and the control enclosure is also shown (Diff)

\begin{tabular}{|c|c|c|c|c|c|c|c|c|c|c|c|c|c|c|c|c|c|c|c|c|c|c|c|c|c|c|c|}
\hline \multirow{3}{*}{$\begin{array}{l}\text { Period } \\
\text { Months } \\
\end{array}$} & \multirow{3}{*}{$\begin{array}{c}\mathrm{N} \\
\text { Samples } \\
\end{array}$} & \multicolumn{8}{|c|}{$\mathrm{pH}_{\mathrm{T}}$} & \multicolumn{6}{|c|}{$p \mathrm{CO}_{2}(\mu \mathrm{atm})$} & \multicolumn{6}{|c|}{$\mathbf{\Omega}_{\mathrm{a}}$} & \multicolumn{6}{|c|}{$\mathbf{\Omega}_{\mathrm{c}}$} \\
\hline & & \multicolumn{2}{|c|}{ Ambient } & \multicolumn{2}{|c|}{ Control } & \multicolumn{2}{|c|}{ Experimental } & \multicolumn{2}{|c|}{ Diff } & \multicolumn{2}{|c|}{ Ambient } & \multicolumn{2}{|c|}{ Control } & \multicolumn{2}{|c|}{ Experimental } & \multicolumn{2}{|c|}{ Ambient } & \multicolumn{2}{|c|}{ Control } & \multicolumn{2}{|c|}{ Experimental } & \multicolumn{2}{|c|}{ Ambient } & \multicolumn{2}{|c|}{ Control } & \multicolumn{2}{|c|}{ Experimental } \\
\hline & & Mean & SD & Mean & SD & Mean & SD & Mean & SD & Mean & SD & Mean & SD & Mean & SD & Mean & SD & Mean & SD & Mean & SD & Mean & SD & Mean & SD & Mean & SD \\
\hline \multicolumn{28}{|l|}{ Before } \\
\hline May & 11840 & 8.10 & 0.03 & 8.12 & 0.06 & 8.01 & 0.05 & -0.10 & 0.03 & 374 & 30 & 358 & 55 & 477 & 74 & 3.4 & 0.2 & 3.5 & 0.4 & 2.9 & 0.3 & 5.3 & 0.3 & 5.4 & 0.5 & 4.5 & 0.5 \\
\hline \multicolumn{28}{|l|}{ Acidification $^{\text {June }}$} \\
\hline June & 6226 & 8.05 & 0.03 & 8.02 & 0.04 & 7.79 & 0.13 & -0.23 & 0.13 & 430 & 42 & 470 & 57 & 868 & 318 & 3.6 & 0.2 & 3.3 & 0.3 & 2.3 & 0.6 & 5.4 & 0.4 & 5.1 & 0.4 & 3.5 & 0.9 \\
\hline July & 21007 & 8.03 & 0.03 & 8.03 & 0.06 & 7.79 & 0.12 & -0.24 & 0.11 & 454 & 46 & 453 & 81 & 870 & 254 & 3.6 & 0.2 & 3.6 & 0.4 & 2.4 & 0.6 & 5.4 & 0.4 & 5.4 & 0.6 & 3.6 & 0.8 \\
\hline August & 22682 & 8.00 & 0.03 & 8.04 & 0.07 & 7.81 & 0.12 & -0.23 & 0.09 & 489 & 42 & 445 & 85 & 834 & 253 & 3.5 & 0.2 & 3.7 & 0.5 & 2.5 & 0.6 & 5.3 & 0.3 & 5.7 & 0.7 & 3.8 & 0.9 \\
\hline September & 21854 & 7.98 & 0.07 & 7.97 & 0.06 & 7.70 & 0.11 & -0.27 & 0.10 & 521 & 96 & 536 & 87 & 1098 & 288 & 3.3 & 0.4 & 3.2 & 0.3 & 2.0 & 0.5 & 5.0 & 0.6 & 4.9 & 0.5 & 3.0 & 0.7 \\
\hline October & 22420 & 8.01 & 0.04 & 8.00 & 0.04 & 7.70 & 0.13 & -0.29 & 0.14 & 480 & 52 & 497 & 64 & 1086 & 390 & 3.4 & 0.2 & 3.3 & 0.3 & 2.0 & 0.5 & 5.1 & 0.4 & 5.0 & 0.4 & 3.0 & 0.8 \\
\hline November & 5377 & 8.02 & 0.03 & 8.02 & 0.02 & 7.80 & 0.15 & -0.22 & 0.15 & 469 & 48 & 467 & 22 & 836 & 305 & 3.2 & 0.2 & 3.2 & 0.1 & 2.2 & 0.7 & 4.9 & 0.3 & 4.9 & 0.2 & 3.5 & 1.0 \\
\hline Before & 24334 & 8.10 & 0.04 & 8.05 & 0.07 & 8.06 & 0.07 & 0.01 & 0.09 & 380 & 39 & 434 & 85 & 426 & 87 & 3.5 & 0.2 & 3.2 & 0.4 & 3.3 & 0.5 & 5.4 & 0.4 & 4.9 & 0.6 & 5.0 & 0.7 \\
\hline Acidification & 95711 & 8.01 & 0.05 & 8.01 & 0.06 & 7.75 & 0.13 & -0.26 & 0.11 & 483 & 67 & 482 & 86 & 971 & 323 & 3.4 & 0.3 & 3.4 & 0.4 & 2.2 & 0.6 & 5.2 & 0.4 & 5.2 & 0.6 & 3.6 & 0.9 \\
\hline
\end{tabular}

